\title{
Chronic cortisol and the regulation of food intake and the endocrine growth axis in rainbow trout
}

\author{
Barry N Madison, Sara Tavakoli, Sarah Kramer and Nicholas J Bernier
}

Department of Integrative Biology, University of Guelph, 50 Stone Road East, Guelph, Ontario, Canada N1G 2W1

Correspondence should be addressed to $\mathrm{N} J$ Bernier

Email nbernier@uoguelph.ca

\begin{abstract}
To gain a better understanding of the mechanisms by which cortisol suppresses growth during chronic stress in fish, we characterized the effects of chronic cortisol on food intake, mass gain, the expression of appetite-regulating factors, and the activity of the GH/IGF axis. Fish given osmotic pumps that maintained plasma cortisol levels at $\sim 70$ or $116 \mathrm{ng} / \mathrm{ml}$ for 34 days were sampled 14,28 and 42 days post-implantation. Relative to shams, the cortisol treatments reduced food intake by $40-60 \%$ and elicited marked increases in liver leptin (lep-a1) and brain preoptic area (POA) corticotropin-releasing factor (crf) mRNA levels. The cortisol treatments also elicited $40-80 \%$ reductions in mass gain associated with increases in pituitary $g h$, liver $g h$ receptor ( $g h r)$, liver igfl and igf binding protein (igfbp)-1 and -2 mRNA levels, reduced plasma GH and no change in plasma IGF1. During recovery, while plasma GH and pituitary gh, liver ghr and igfl gene expression did not differ between treatments, the high cortisol-treated fish had lower plasma IGF1 and elevated liver igfbp1 mRNA levels. Finally, the cortisol-treated fish had higher plasma glucose levels, reduced liver glycogen and lipid reserves, and muscle lipid content. Thus, our findings suggest that the growth-suppressing effects of chronic cortisol in rainbow trout result from reduced food intake mediated at least in part by increases in liver lep-a1 and POA crf mRNA, from sustained increases in hepatic igfbp 1 expression that reduce the growth-promoting actions of the GH/IGF axis, and from a mobilization of energy reserves.
\end{abstract}
Key Words
- chronic stress
- food intake
- growth regulation
- GH/IGF1 system

$\checkmark$ fish

\section{Introduction}

The chronic stress associated with a variety of adverse environmental conditions has been shown to suppress somatic growth in fish. For example, prolonged crowding (Pickering \& Pottinger 1989, Trenzado et al. 2006), repeated handling (Barton et al. 1987, Hoskonen \& Pirhonen 2006), poor water quality (Schram et al. 2009) and social subordination (DiBattista et al. 2006) are common chronic stressors in aquaculture that reduce growth rates. These stressors also activate the hypothalamic-pituitary-interrenal axis and as a result are associated with an increase in the circulating levels of the primary glucocorticoid in teleosts fish, cortisol (Wendelaar Bonga 1997, Bernier et al. 2009). Since glucocorticoids promote the mobilization and redistribution of energy, the effects of chronic stress on growth in fish have generally been attributed to the actions of cortisol (Pickering 1992, Pankhurst \& Van Der Kraak 1997, Small et al. 2008). Although studies using exogenous

Published by Bioscientifica Ltd. 
cortisol have previously linked the growth-suppressing effects of cortisol in fish to its actions on food intake, intermediary metabolism and muscle mass regulation (reviewed by Mommsen et al. (1999), Bernier (2006) and Picha et al. (2008)), the precise mechanisms by which cortisol affects these complex systems are far from clear.

Cortisol affects food intake in fish but its primary effect and mechanism of action are unresolved. While the primary effect of glucocorticoids in mammals and amphibians is to increase food intake (Crespi et al. 2004, Bazhan $\&$ Zelena 2013), the actions of cortisol on appetite in fish are equivocal. Whereas chronic exposure to a low dose of cortisol stimulated food intake in goldfish (Carassius auratus; Bernier et al. 2004), sustained exposure to higher doses of cortisol decreased food intake in several fish species (Gregory \& Wood 1999, Bernier et al. 2004, Peterson \& Small 2005, Leal et al. 2011). In mammals, glucocorticoids promote food intake by stimulating the hypothalamic expression of the orexigenic neuropeptides neuropeptide Y (NPY) and agouti-related peptide (AgRP), and by inhibiting the anorexigenic signal corticotropinreleasing factor (CRF; Bazhan \& Zelena 2013). Similarly, the stimulatory effects of cortisol on food intake in goldfish are associated with an increase in hypothalamic NPY mRNA levels and a reduction in preoptic area (POA) CRF gene expression (Bernier et al. 2004). In contrast, the pathways mediating the anorexigenic effects of cortisol in fish have yet to be identified (Bernier et al. 2004, Leal et al. 2011). In mammals, glucocorticoids are a potent stimulator of adipocyte leptin expression and secretion, and under conditions of glucocorticoid excess leptin can counteract the orexigenic effects of cortisol (Leal-Cerro et al. 2001, Lee \& Fried 2009). The primary site of leptin expression in fish is the liver (Londraville et al. 2014). Whether the anorexigenic effects of cortisol in fish are at least partly mediated by an increase in hepatic leptin expression is not known.

Somatic growth in fish, as in other vertebrates, is primarily mediated by the growth hormone (GH)/insulinlike growth factor 1 (IGF1) axis (reviewed by Wood et al. (2005) and Reindl \& Sheridan (2012)) and to better understand how stressors impact growth several studies have recently described the effects of exogenous cortisol and stressors on the activity of this endocrine system. However, despite the fact that growth suppression is a feature of chronic stress, the large majority of these studies only focused on the short-term effects of stress (i.e. $<48 \mathrm{~h}$ ). Overall, on an acute time scale, cortisol injections or stressors in fish either have no effect or decrease plasma GH levels, reduce liver igf1 gene expression and plasma IGF1 levels, counteract GH stimulation of liver igf 1 transcription, and increase the hepatic expression and plasma levels of low molecular weight IGF binding proteins (IGFBPs) (Kelley et al. 2001, Kajimura et al. 2003, Pierce et al. 2005, Wilkinson et al. 2006, Leung et al. 2008, Saera-Vila et al. 2009, Breves et al. 2010, Shepherd et al. 2011, Nakano et al. 2013). In channel catfish (Ictalurus punctatus), chronic dietary cortisol had no effect on liver igf1 mRNA levels, reduced plasma IGF1, and increased the plasma levels of low molecular weight IGFBPs (Peterson \& Small 2005). Whether chronic cortisol exposure has similar effects on the GH/IGF1 system in other fish species or whether these effects are sustained once cortisol has returned to baseline levels have not been investigated.

In this study, to identify the mechanisms by which chronic cortisol suppresses growth in rainbow trout (Oncorhynchus mykiss), we characterized the effects of a 34-day period of sustained moderate physiological levels of cortisol on food intake, mass gain, the plasma levels of GH and IGF1, and the gene expression of key appetite- and growth-regulating factors. To determine whether the cortisol dosages used promote the mobilization of energy, we assessed the status of liver and white muscle carbohydrate and lipid reserves. To gain a better understanding of whether the effects of chronic cortisol are sustained once cortisol levels have returned to baseline, we also quantified the above parameters 8 days post cortisol exposure. Finally, we used trout hepatocytes in primary culture to determine whether the in vivo stimulatory effects of cortisol on liver leptin gene expression are direct.

\section{Materials and methods}

\section{Experimental animals}

Sexually immature rainbow trout $(n=72 ; 192 \pm 3 \mathrm{~g})$ of mixed sex were obtained from Rainbow Springs Trout Farm (Thamesford, ON, Canada) and housed at the University of Guelph. Fish were acclimated in 700-1 fiberglass tanks with flow-through well water on a $12 \mathrm{~h}$ light: $12 \mathrm{~h}$ darkness photoperiod for several weeks prior to the onset of experiments. Water conditions were maintained at $12 \pm 1{ }^{\circ} \mathrm{C}$, $\mathrm{pH}$ of $7.8 \pm 0.2$ during the acclimation and the experimental period. Fish were fed $2 \%$ body weight (BW) daily with commercial trout food (3 pt Classic Sinking, Martin Mills, Elmira, ON, Canada). All procedures were carried out in accordance with the Canadian Council for Animal Care guidelines and approved by the University of Guelph Animal Care Committee (protocol 05R074).

Published by Bioscientifica Ltd 


\section{Experimental protocol}

In vivo cortisol treatment Fish were anesthetized in buffered $\left(\mathrm{NaHCO}_{3}, 0.2 \mathrm{~g} / \mathrm{l}\right)$ tricaine methanesulfonate (0.1 g/l, Syndel International, Qualicum Beach, BC, Canada), weighed and implanted intramuscularly with a $125 \mathrm{KHz}$ passive integrative transponder $(11.5 \times 2.1 \mathrm{~mm}$, Biomark, Boise, ID, USA) tag for individual identification. Fish were then transferred into 125 -l tanks ( $n=8$ per tank) and allowed to acclimate for 2 weeks. After this acclimation period, fish were anesthetized as above to measure fork length and BW, and to implant micro-osmotic pumps (Alzet model \#1007D, Durect Corporation, Cupertino, CA, USA) into the peritoneal cavity. While control fish (Sham) were implanted with pumps containing a $65 \%$ solution of the steroid miscible vehicle 2-hydroxypropyl- $\beta$-cyclodextrin (Molecusol HBP, Sigma-Aldrich), cortisol groups were implanted with pumps containing $20 \mu \mathrm{g} / \mathrm{g}$ BW (Cort-I) or $40 \mu \mathrm{g} / \mathrm{g} \mathrm{BW}$ (Cort-II) cortisol (hydrocortisone, SigmaAldrich) dissolved in 65\% Molecusol HBP. Molecusol HBP was used as a non-toxic complexing agent to increase the aqueous solubility of cortisol and minimize the size of the micro-osmotic pumps needed to perform the chronic exposure. The cortisol dosage levels were chosen on the basis of plasma cortisol concentrations achieved during a pilot study. At a water temperature of $12^{\circ} \mathrm{C}$, it was calculated and confirmed in preliminary experiments that the osmotic pumps deliver cortisol for a period of 34 days. Sham, Cort-I and Cort-II fish were terminally sampled at 14, 28 and 42 days post osmotic pump implantation.

At the time of terminal sampling, all fish in a given tank were anesthetized at once with a lethal dose of 2-phenoxyethanol (2 ml/l, Sigma-Aldrich) and a blood sample was immediately taken via caudal puncture using a $\mathrm{K}_{2}$ EDTA (0.5 M, pH 8.0)-treated syringe. Blood samples were immediately centrifuged at $14000 \boldsymbol{g}$ for $3 \mathrm{~min}$ and the separated plasma was aliquoted and flash frozen in liquid nitrogen prior to storage at $-80^{\circ} \mathrm{C}$ for later analysis of plasma cortisol, adrenocorticotropic hormone (ACTH), GH, IGF1 and glucose. Fork length and BW were then recorded, and several tissues were collected to quantify the mRNA levels of key appetite- and growth-regulating genes by quantitative real-time RT-PCR (qRT-PCR) or tissue metabolite levels. The brain was removed and regionally dissected (Bernier et al. 2008) to isolate the POA and the hypothalamus. Whole pituitary and liver, and a standardized sample of white muscle (rostral to dorsal fin) were also collected. All tissues were immediately frozen in liquid nitrogen and stored at $-80{ }^{\circ} \mathrm{C}$ for future analysis.
Primary culture of trout hepatocytes To determine whether the actions of cortisol on hepatic leptin-A1 gene expression (lep-1a) are direct and mediated by glucocorticoid receptors (GR), we exposed primary cultures of trout hepatocytes in vitro to cortisol or a combination of cortisol and RU486 (a GR antagonist). Trout hepatocytes were isolated by in situ perfusion of liver with collagenase (Sigma) as previously described (Sathiyaa et al. 2001). Trypan blue dye exclusion method was used to confirm hepatocyte viability and $>95 \%$ cells were viable. Cells were plated in six-well tissue culture plates (Sarstedt, Inc., Newton, NC, USA) at a density of 1.5 million cells/well (0.75 million cells $/ \mathrm{ml})$ in L-15 media and were maintained at $12^{\circ} \mathrm{C}$ for $24 \mathrm{~h}$. After $24 \mathrm{~h}$, the L-15 media was replaced with either fresh L-15 (control; containing $0.01 \%$ ethanol as vehicle), L-15 containing cortisol $(100 \mathrm{ng} / \mathrm{ml})$, or L-15 with a combination of cortisol (100 ng/ml) and RU486 (1000 ng/ml), and cells were maintained at $12{ }^{\circ} \mathrm{C}$ for $24 \mathrm{~h}$ before sampling. In the combination treatment, RU486 was added to the cells $30 \mathrm{~min}$ before cortisol addition. All the experiments were repeated with hepatocytes isolated from six different fish.

\section{Analytical techniques}

Food intake quantification To prevent the formation of within tank social hierarchies, fish were carefully selected to minimize size differences within and between treatments, and fish in each tank were slowly hand fed to satiation daily throughout the acclimation and experimental periods. Individual food intake was quantified by X-ray radiography on the day of terminal sampling (Bernier \& Craig 2005). Fish were fed to satiation with re-pelleted food containing $450 \mu \mathrm{m}$ carbon steel beads (Draiswerke, Inc., Mahwah, NJ, USA) at a ratio of $5 \%$ by mass of dry powdered feed. Ninety minutes following feeding fish were terminated with an overdose of 2-phenoxyethanol as above and Xrayed using an ACU-RAY HFJ portable X-ray unit (50 kVp, 1.05 mAs @ 90 cm; Sterne, ON, Canada). After development of the radiographs, the number of steel beads in the gastrointestinal tract was tallied and the amount of feed consumed calculated using a calibration curve.

Quantification of growth rate and physical indices Specific growth rate (SGR, in \% $\mathrm{BW} / d$ ) was derived from initial $\mathrm{BW}\left(W_{0}\right)$, final BW $\left(W_{1}\right)$ and the length of the sampling interval $(t$, in days $)$, and calculated as: SGR $=\left(\left(\ln W_{1}-\ln \right.\right.$

Published by Bioscientifica Ltd 
$\left.\left.W_{0}\right) / t\right) \times 100$. Condition factor $(\mathrm{CF})$ was derived from $\mathrm{BW}$ $(W, \mathrm{~g})$ and fork length $(L, \mathrm{~cm})$ and calculated as: $\mathrm{CF}=$ $\left(W / L^{3}\right) \times 100$. Hepatosomatic index (HSI, in \%) was derived from the weight of the liver $\left(W_{\mathrm{L}}\right)$ and $\mathrm{BW}$, and calculated as: $\mathrm{HSI}=\left(W_{\mathrm{L}} / \mathrm{BW}\right) \times 100$.

Plasma analyses Plasma cortisol concentrations were measured in triplicate by RIA as per the methods of Bernier et al. (2008). The lower detection of the assay was $16 \mathrm{pg} / \mathrm{ml}$. The intra- and inter-assay coefficients of variation were $3.2 \%(n=6)$ and $5.3 \%(n=6)$ respectively. Plasma ACTH levels were measured in duplicate following the procedures outlined in the ImmuChem Double Antibody hACTH RIA kit (product code \#07106101; MP Biomedicals, Orangeburg, NY, USA). This assay was previously validated for use with rainbow trout plasma (Craig et al. 2005). All samples were analyzed in one assay that had a lower detection limit of $10 \mathrm{pg} / \mathrm{ml}$ and an intra-assay variation of $5.1 \%(n=8)$. Furthermore, a serial dilution of rainbow trout plasma gave a displacement curve parallel to the ACTH standard curve. Plasma IGF1 levels were assayed as described in Shimizu et al. (2000). Briefly, total IGF1 was first separated from binding proteins within the plasma by acid-ethanol and quantified using recombinant trout IGF1 as standard and tracer, and anti-recombinant barramundi IGF1 as primary antibody (1:7000; Novozymes GroPep Ltd, Adelaide, Australia). Plasma GH levels were assayed as described by Swanson (1994) using recombinant trout $\mathrm{GH}$ as standard and tracer and anti-recombinant trout $\mathrm{GH}$ as primary antibody (1:25 000; Novozymes GroPep Ltd). IGF1 and GH were iodinated by the chloramine-T method. For both the IGF1 and GH RIAs, $7000 \mathrm{cpm}$ of tracer in $50 \mu \mathrm{l}$ was added to tubes containing $50 \mu \mathrm{l}$ of sample, $50 \mu \mathrm{l}$ of primary antibody and $150 \mu$ l of RIA buffer $(30 \mathrm{mM}$ $\mathrm{NaH}_{2} \mathrm{PO}_{4}, 0.02 \%$ protamine sulphate, $10 \mathrm{mM}$ EDTA, $0.025 \% \mathrm{NaN}_{3}, 0.05 \%(\mathrm{v} / \mathrm{v})$ Tween-20, pH 7.5). After a $48 \mathrm{~h}$ incubation at $4{ }^{\circ} \mathrm{C}$, the antibody-bound IGF1 or GH were complexed with secondary antibody (1:15, goat anti-rabbit IgG; AbD Serotec, Oxford, UK) and polyclonal rabbit anti-human IgG (1:200; Dako, Glostrup, Denmark), and precipitated by using ice-cold polyethylene glycol 6000 (PEG-6000; Sigma-Aldrich) and centrifugation at $4000 \boldsymbol{g}$ for $30 \mathrm{~min}$. Plasma IGF1 and GH analyses were each performed in a single assay. The lower detection limit of each RIA was $<0.5 \mathrm{ng} / \mathrm{ml}$ and the intra-assay coefficients of variability for the IGF1 and GH assays were $4.0 \%(n=6)$ and $0.5 \%(n=6)$ respectively. Concentrations of plasma cortisol, ACTH, IGF1 and GH were determined using three-parameter sigmoidal curve regression equations (SigmaPlot 10, SPSS) obtained from the standard curves. Plasma glucose was determined using the standard $\mathrm{NAD}^{+}$-coupled enzymatic procedure described in Bergmeyer (1985) and modified for use with microplates and a SpectraMAX 190 spectrophotometer (Molecular Devices, Menlo Park, CA, USA).

Tissue metabolite analyses Tissue glycogen content was measured using a modification of the method described by Bergmeyer (1985). Approximately $100 \mathrm{mg}$ of liver or white muscle was homogenized (Euro Turrax T20b, IKA Labortechnik, Staufen, Germany) on ice for $1 \mathrm{~min}$ at approximately $12000 \mathrm{~g}$ in acetate buffer, $\mathrm{pH} 4.8$ (Bergmeyer 1985). Glycogen in the resultant homogenate was converted to glucose by amyloglucosidase and free glucose was measured using an $\mathrm{NAD}^{+}$-coupled enzymatic reaction catalyzed by hexokinase and modified for use with a microplate spectrophotometer. Total liver and white muscle lipid content was gravimetrically measured on a separate set of tissue samples $(\sim 100 \mathrm{mg})$ using the 2:1 chloroform-methanol extraction method of Folch et al. (1957). Water content of liver and muscle tissue was determined by weight differential via desiccation in an oven at $70{ }^{\circ} \mathrm{C}$ for 2 days. All metabolite measures were corrected for tissue water content.

Quantification of gene expression Tissues were homogenized and total RNA extracted using Trizol Reagent (Life Technologies). RNA pellets were then re-dissolved in RNase-free water and quantified by ultraviolet spectrophotometry at $260 \mathrm{~nm}$ (Nanodrop 8000; Nanodrop Products, Wilmington, DE, USA). Integrity of the isolated RNA was ensured prior to cDNA synthesis by analyzing a random subset of samples on a $1.5 \%$ agarose gel. One microgram of total RNA was treated with DNase I (Life Technologies) and reverse transcribed to cDNA using Superscript II RNase H-reverse transcriptase (Life Technologies) according to the manufacturer's protocol. Non-reverse transcribed (no-RT controls) representatives from each tissue and treatment were included during cDNA synthesis to monitor genomic contamination. Triplicates of each cDNA sample were amplified by real-time PCR using an ABI Prism 7000 sequence detection system (Applied Biosystems). The $20 \mu \mathrm{l}$ reactions contained $10 \mu \mathrm{l} 2 \mathrm{X}$ SYBR Green PCR Master Mix (Applied Biosystems), $5 \mu \mathrm{l}$ of 15-fold diluted first strand cDNA template or no-RT

Published by Bioscientifica Ltd 
controls and $2.5 \mu \mathrm{l}$ of both forward and reverse primers $(0.4 \mu \mathrm{M})$. Default cycling conditions were used and followed by a melting curve analysis to verify the specificity of each PCR product. Only samples with a unimodal dissociation curve and predicted melting temperature were analyzed. Primer pairs for qPCR were designed using Primer Express 3.0 (Applied Biosystems) based on rainbow trout sequences for each targeted gene (Table 1). To account for differences in amplification efficiency, standard curves were constructed for each gene using known dilutions of cDNA from the targeted tissues. Input values for each gene were obtained by fitting the average threshold cycle $\left(C_{\mathrm{T}}\right)$ value to the antilog of the gene-specific standard curve thereby correcting for differences in primer amplification efficiency. To correct for minor variations in template input and transcriptional efficiency, the input values were normalized to the housekeeping gene elongation factor $1 \alpha(e f 1 \alpha)$. Note that the expression of ef $1 \alpha$ did not differ between any of the treatments
$(P>0.05)$. Gene expression data is reported as fold change relative to the 14 -day Sham treatment mean value.

\section{Statistical analyses}

Results are presented as mean \pm s.E.M. A two-way ANOVA followed by a Holm-Sidak post-hoc test for multiple comparisons was used to determine the effects of treatment and time on all the parameters measured in the in vivo cortisol treatment. A one-way ANOVA followed by a Holm-Sidak test was used to determine the effects of treatment on lep-a1 mRNA levels in the in vitro cultured hepatocytes. Data that did not meet the assumption of normality were log-transformed prior to analysis. Data presented in percentage were arcsine transformed prior to analysis. The relationships between plasma IGF1 levels and SGR within the Sham, Cort-I and Cort-II treatments were analyzed using Pearson's Product Moment Correlation test. All analyses were performed using SigmaPlot

Table 1 Nucleotide sequences of rainbow trout primers used for qRT-PCR

\begin{tabular}{|c|c|c|c|}
\hline Gene & Accession no. & Efficiency (\%) & Sequence $\left(5^{\prime}-3^{\prime}\right)$ \\
\hline agrp & CR376289 & 90.8 & $\begin{array}{l}\text { F: ACCAGCAGTCCTGTCTGGGTAA } \\
\text { R: AGTAGCAGATGGAGCCGAACA }\end{array}$ \\
\hline cart & CA380644 & 91.7 & $\begin{array}{l}\text { F: CCTCGACACAAGAAGTGTGAGAGA } \\
\text { R: TGTAGTGCTCCAAGCAGTTGCT }\end{array}$ \\
\hline$c r f$ & AF296672 & 90.8 & $\begin{array}{l}\text { F: ACAACGACTCAACTGAAGATCTCG } \\
\text { R: AGGAAATTGAGCTTCATGTCAGG }\end{array}$ \\
\hline ef1 $\alpha$ & AF498320 & 96.0 & $\begin{array}{l}\text { F: CCATTGACATTTCTCTGTGGAAGT } \\
\text { R: GAGGTACCAGTGATCATGTTCTTGA }\end{array}$ \\
\hline gh1 & M22731 & 101.5 & $\begin{array}{l}\text { F: TCAAGAAGGACATGCACAAGGT } \\
\text { R: TCTCCAGCCCACGTCTACAGA }\end{array}$ \\
\hline$g h 2$ & M24684 & 94.3 & $\begin{array}{l}\text { F: GGGTTTTCAAGCATTTTGGCATT } \\
\text { R: ATGGATCAGTGGTAGCTCCGAGTA }\end{array}$ \\
\hline$g h r 2^{a}$ & AY861675/AY751531 & 96.9 & $\begin{array}{l}\text { F: TGGAAGACATCGTGGAACCA } \\
\text { R: CATTCAGCAGGGTCCAGTTCA }\end{array}$ \\
\hline igf1 & M95183 & 92.1 & $\begin{array}{l}\text { F: GATGTCTTCAAGAGTGCGATGTG } \\
\text { R: CGCCGAAGTCAGGGTTAGG }\end{array}$ \\
\hline igfbp 1 & NM_001124561 & 91.0 & $\begin{array}{l}\text { F: AGGGTCCCTGCCACATTGA } \\
\text { R: CTAGTTCCTGCTGAGAGCTGGTT }\end{array}$ \\
\hline igfbp2 & DQ146968 & 91.1 & $\begin{array}{l}\text { F: CGCCTCAGCCCAGAAATAGT } \\
\text { R: GTTTTAAGACTCAGGCCGATCAG }\end{array}$ \\
\hline lep-a1 & AB354909 & 95.1 & $\begin{array}{l}\text { F: GAGGGCATGGACCCATTTC } \\
\text { R: GGCAGGCTTTCTATATGCTGATC }\end{array}$ \\
\hline npy & AF203902 & 99.8 & $\begin{array}{l}\text { F: CGGTCAAACCCGAAAATCC } \\
\text { R: TCTTCCCATACCTCTGCCTTGT }\end{array}$ \\
\hline pomc-a2 & X69808 & 87.4 & $\begin{array}{l}\text { F: CTGAAAACAACCTCCTGGAGTGT } \\
\text { R: GAGAGGAGGGACAGAGGTAAGTAGAG }\end{array}$ \\
\hline
\end{tabular}

agrp, agouti-related protein; cart, cocaine- and amphetamine-regulated transcript; crf, corticotropin-releasing factor; ef $1 \alpha$, elongation factor $1 \alpha ; F_{\text {, forward; }}$ gh, growth hormone; ghr2, GH receptor type 2; igf1, insulin-like growth factor I; igfbp, IGF binding protein; lep-a1, leptin-A1; npy, neuropeptide Y; pomc-a2, pro-opiomelanocortin A2; R, reverse.

aprimers for ghr2 amplify coding regions that are $100 \%$ homologous between the GHR2a and GHR2b paralogues (see Reindl \& Sheridan (2012) for nomenclature).

http://joe.endocrinology-journals.org DOI: $10.1530 / J O E-15-0186$
(C) 2015 Society for Endocrinology Printed in Great Britain
Published by Bioscientifica Ltd. 
12.5 (SPSS). The significance level for all statistical tests was $P<0.05$.

\section{Results}

\section{Plasma cortisol, plasma ACTH and pituitary pomc gene expression}

Plasma cortisol in the three Sham groups did not differ from one another and averaged $6.0 \pm 0.5 \mathrm{ng} / \mathrm{ml}$. Fish implanted with cortisol-filled osmotic pumps had consistent plasma cortisol concentrations of $69.5 \pm 0.9 \mathrm{ng} / \mathrm{ml}$ (Cort-I) and $115.7 \pm 1.7 \mathrm{ng} / \mathrm{ml}$ (Cort-II) over the 14 and 28 day sampling periods (Fig. 1A). At 42 days, 8 days after the pumps had run out, the cortisol-treated fish had plasma cortisol concentrations that did not differ from the Sham treatment. Plasma ACTH concentrations in the cortisol-treated fish were reduced to less than half of the levels observed in the Sham treatment at 14 and 28 days (Fig. 1B). At 42 days, while plasma ACTH levels in the Cort-I treatment returned to the basal value of the Sham treatment, they remained low in the Cort-II treatment. Pituitary pro-opiomelanocortin A2 (pomc-a2) mRNA levels in the Cort-I and -II treatments were lower than in the Sham treatment during the first 14 and 28 days of the experiment, respectively, and recovered to basal levels at 42 days (Fig. 1C).

\section{Food intake, growth performance and physical indices}

The cortisol treatments equally suppressed feeding throughout the cortisol and recovery periods (Fig. 2A). On average, over the 42-day experiment and relative to the time-matched Sham treatments, the Cort-I and -II treatments decreased food intake by 43 and 53\% respectively. Exogenous cortisol significantly reduced mass gained in a dose-dependent manner (Fig. 2B). Although there was no difference in initial BW between any of the groups (Sham: 195.3 \pm 6.3 g; Cort-I: $188.8 \pm 5.2$ g; Cort-II: $192.1 \pm 4.1 \mathrm{~g})$, by the end of the 42 -day trial the Sham fish had nearly doubled their mass while the Cort-I and -II fish increased BW by only 50 and 15\% respectively. Relative to the Sham groups, the Cort-I and -II treatments elicited sustained dose-dependent reductions in SGR throughout the cortisol and recovery periods, but the growthsuppressing effects of cortisol only reached statistical significance in the Cort-II treatment (Fig. 2C). On average, over the 42-day experiment and relative to the timematched Sham treatments, the Cort-I and -II treatments decreased SGR by 43 and 70\% respectively. Over the
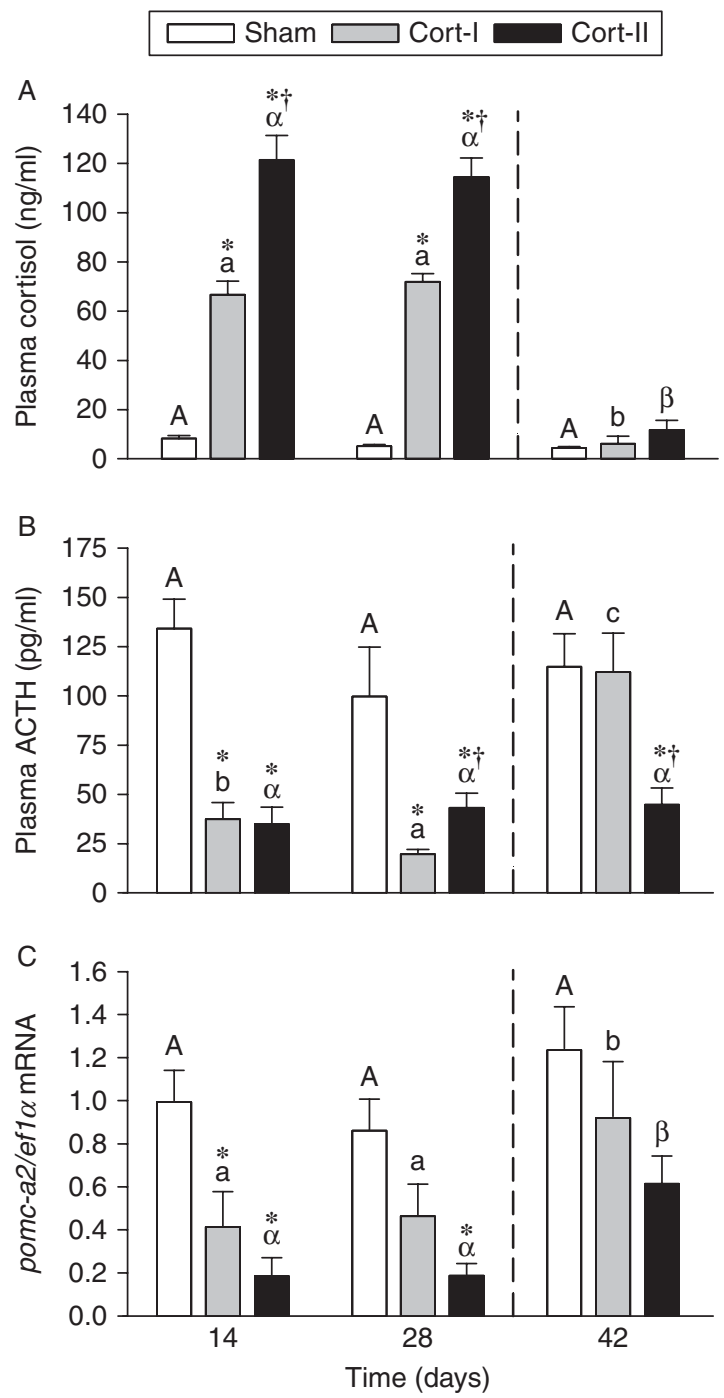

Figure 1

(A) Plasma cortisol (B) plasma ACTH and (C) pituitary pro-opiomelanocortin A2 (pomc-a2) mRNA expression in rainbow trout implanted intraperitoneally with a micro-osmotic pump containing either vehicle (Sham), $20 \mu \mathrm{g}$ (Cort-I) or $40 \mu \mathrm{g}$ cortisol/g BW (Cort-II). Cortisol treatments terminated at 34 days as indicated by the dashed line. The mRNA expression values are normalized with elongation factor $1 \alpha(e f 1 \alpha)$ and the expression ratios are presented relative to the Sham 14-day treatment. Statistical differences between values were determined by a two factor ANOVA and Holm-Sidak post-hoc test: cortisol (treatment: $P<0.001$, time: $P<0.001$, treatment $\times$ time: $P<0.001$ ), ACTH (treatment: $P<0.001$, time: $P<0.001$, treatment $\times$ time: $P<0.001$ ) and pomc-a2 mRNA expression (treatment: $P<0.001$, time: $P=0.001$, treatment $\times$ time: $P=0.322$ ). Bars for a given parameter and treatment that do not share a common letter are different from one another. At a given time, a difference from the Sham treatment is indicated by * and a difference between the cortisol treatments is indicated by $\dagger(P<0.05)$. Values are means + S.E.M. $(n=8)$.

course of the experiment, fork length increased by 17.9 and $7.2 \%$ in the Sham and Cort-I treatments, respectively, and did not change in the Cort-II treatment (Table 2). While CF increased over the 42-day trial in the Sham fish,

Published by Bioscientifica Ltd. 

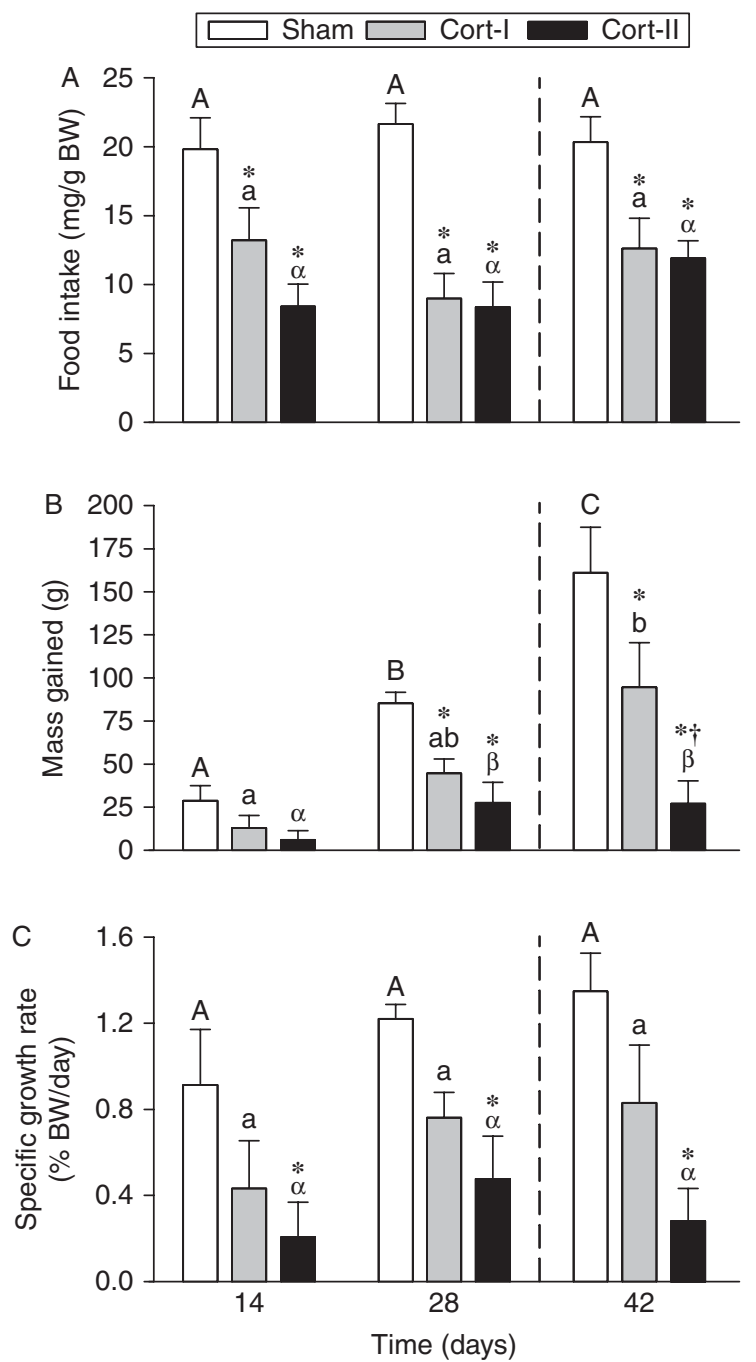

Figure 2

(A) Food intake, (B) mass gained and (C) specific growth rate in rainbow trout implanted intraperitoneally with a micro-osmotic pump containing either vehicle (Sham), $20 \mu \mathrm{g}$ (Cort-I) or $40 \mu \mathrm{g}$ cortisol/g BW (Cort-II). Cortisol treatments terminated at 34 days as indicated by the dashed line. Statistical differences between values were determined by a two factor ANOVA and Holm-Sidak post-hoc test: food intake (treatment: $P<0.001$, time: $P=0.423$, treatment $\times$ time: $P=0.373$ ), mass gained (treatment: $P<0.001$, time: $P<0.001$, treatment $\times$ time: $P=0.007$ ) and specific growth rate (treatment: $P<0.001$, time: $P=0.103$, treatment $\times$ time: $P=0.802$ ). Bars for a given parameter and treatment that do not share a common letter are different from one another. At a given time, a difference from the Sham treatment is indicated by * and a difference between the cortisol treatments is indicated by $+(P<0.05)$. Values are means + S.E.M. $(n=8)$.

it remained unchanged in the cortisol-treated fish. HSI remained constant in the Sham treatment over the 42-day trial. Conversely, relative to the sham group, HSI decreased by $28 \%$ in the Cort-II fish by 28 days and was reduced by 24 and $27 \%$ in the Cort-I and -II treatments at 42 days respectively.

\section{Expression of selected genes involved in food intake regulation}

Hypothalamic npy, agrp, pomc-a2, cocaine- and amphetamine-regulated transcript (cart), POA crf and liver lep-a1 mRNA levels remained unchanged over the course of the experiment in the Sham treatment (Fig. 3). Relative to Sham, npy gene expression were 2.1- and 3.5-fold higher in the Cort-I and -II treatments at 14 days, remained elevated in the Cort-II treatment at 28 days, and returned to basal levels in both cortisol treatments at 42 days (Fig. 3A). Although the agrp mRNA levels did not differ between the Sham and Cort-I treatments, agrp gene expression was $68 \%$ lower in the Cort-II treatment than in Sham at 14 days and recovered thereafter to control levels (Fig. 3B). Hypothalamic pomc-a2 and cart gene expression in the Cort-I and -II treatments did not differ from the Sham treatment (Fig. 3C and D). POA crf mRNA levels in the Cort-II treatment were more than twofold higher than control levels throughout the experiment, and did not differ between the Cort-I and Sham treatments (Fig. 3E). In the Cort-I treatment, liver lep-a1 mRNA levels were 3.1-fold higher than Sham at 14 days but did not differ from control levels thereafter (Fig. 3F). In contrast, lep-a1 mRNA levels in the Cort-II treatment were 4.1- and 8.6-fold higher than Sham at 14 and 28 days respectively, and remained 2.4 -fold higher than control levels at 42 days (Fig. 3F).

\section{Expression of leptin in isolated hepatocytes}

In the cortisol treatment, hepatocyte lep-a1 mRNA levels were 2.3-fold higher than in the control treatment (Fig. 4). In the combination group, the cortisol-mediated increase in lep-a1 gene expression was abolished by RU486.

\section{Expression of selected genes and hormones involved in growth regulation}

Although significant main treatment effects were observed for pituitary $g h 1 \mathrm{mRNA}$ levels $(P=0.002)$, pituitary $g h 2$ mRNA levels $(P<0.001)$ and plasma GH levels $(P=0.007)$, higher variability for these parameters resulted in few posthoc treatment-specific differences (Fig. 5). In general, each cortisol treatment had similar effects on pituitary $g h 1$ and gh2 gene expression (Fig. 5A and B). Relative to the sham treatment, the cortisol treatments were associated with higher pituitary gh gene expression at 14 days, higher and lower pituitary $g h$ mRNA levels in the Cort-I and -II treatments at 28 days, respectively, and a return to basal conditions at 42 days. In contrast, the cortisol treatments

Published by Bioscientifica Ltd. 
Table 2 Fork length, condition factor and hepatosomatic index (HSI) of rainbow trout implanted with either vehicle(Sham) or cortisol-filled (Cort-I and -II) micro-osmotic pumps for 14, 28 and 42 days

\begin{tabular}{|c|c|c|c|c|}
\hline \multirow[b]{2}{*}{ Parameter } & \multirow[b]{2}{*}{ Treatment } & \multicolumn{3}{|c|}{ Time (days) } \\
\hline & & 14 & 28 & $42^{\ddagger}$ \\
\hline \multirow[t]{3}{*}{ Fork length $(\mathrm{cm})$} & Sham & $25.4 \pm 0.5^{\mathrm{A}}$ & $26.4 \pm 0.4^{\mathrm{A}}$ & $27.6 \pm 0.7^{B}$ \\
\hline & Cort-I & $24.2 \pm 0.4^{\mathrm{a}}$ & $25.3 \pm 0.6^{\mathrm{a}}$ & $26.2 \pm 0.8^{b}$ \\
\hline & Cort-II & $24.5 \pm 0.6^{\alpha}$ & $24.5 \pm 0.4^{\alpha}$ & $24.4 \pm 0.3^{\alpha, \star, \dagger}$ \\
\hline \multirow[t]{3}{*}{ Condition factor $\left(\mathrm{g} / \mathrm{cm}^{3}\right)$} & Sham & $1.38 \pm 0.03^{\mathrm{A}}$ & $1.61 \pm 0.03^{B}$ & $1.68 \pm 0.08^{\mathrm{B}}$ \\
\hline & Cort-I & $1.41 \pm 0.07^{\mathrm{a}}$ & $1.41 \pm 0.04^{a}$ & $1.52 \pm 0.08^{a}$ \\
\hline & Cort-II & $1.45 \pm 0.06^{\alpha}$ & $1.47 \pm 0.04^{\alpha}$ & $1.45 \pm 0.09^{\alpha, *}$ \\
\hline \multirow[t]{3}{*}{ HSI (\%) } & Sham & $1.62 \pm 0.13^{\mathrm{A}}$ & $1.90 \pm 0.11^{\mathrm{A}}$ & $1.69 \pm 0.12^{\mathrm{A}}$ \\
\hline & Cort-I & $1.69 \pm 0.15^{a}$ & $1.64 \pm 0.18^{a}$ & $1.29 \pm 0.14^{a, *}$ \\
\hline & Cort-II & $1.62 \pm 0.12^{\alpha}$ & $1.37 \pm 0.13^{\alpha_{*} *}$ & $1.23 \pm 0.11^{\alpha, *}$ \\
\hline
\end{tabular}

Values are means \pm s.E.M. $(n=8)$. Statistical differences between values were determined by a two factor ANOVA and Holm-Sidak post-hoc test: fork length (treatment: $P=0.001$, time: $P=0.011$, treatment $\times$ time: $P=0.203$ ), condition factor (treatment: $P=0.079$, time: $P=0.026$, treatment $\times$ time: $P=0.15$ ) and HSI (treatment: $P=0.017$, time: $P=0.037$, treatment $\times$ time: $P=0.147$ ). Values for a given parameter and treatment that do not share a common letter are different from one another. At a given time, a difference from the Sham treatment is indicated by * and a difference between the cortisol treatments is indicated by $+(P<0.05)$.

The 42-day fish were sampled 8 days after the osmotic pumps ran out.

were generally associated with a sustained reduction in plasma GH levels (Fig. 5C). While liver ghr2 gene expression did not differ between the Sham and Cort-I treatments, ghr2 mRNA levels were 1.9- and 4.2-fold higher in the Cort-II treatment than in Sham at 14 and 28 days, respectively, and recovered thereafter to control levels (Fig. 5D).
The cortisol treatments also elicited 1.9- to 3.2-fold dose-dependent increases in liver igf1 mRNA levels through the first 28 days of the experiment followed by a return to sham levels at 42 days (Fig. 6A). However, plasma IGF1 levels did not differ between the sham- and cortisol-treated fish during the exogenous cortisol delivery period and were $60 \%$ lower in the Cort-II treatment than
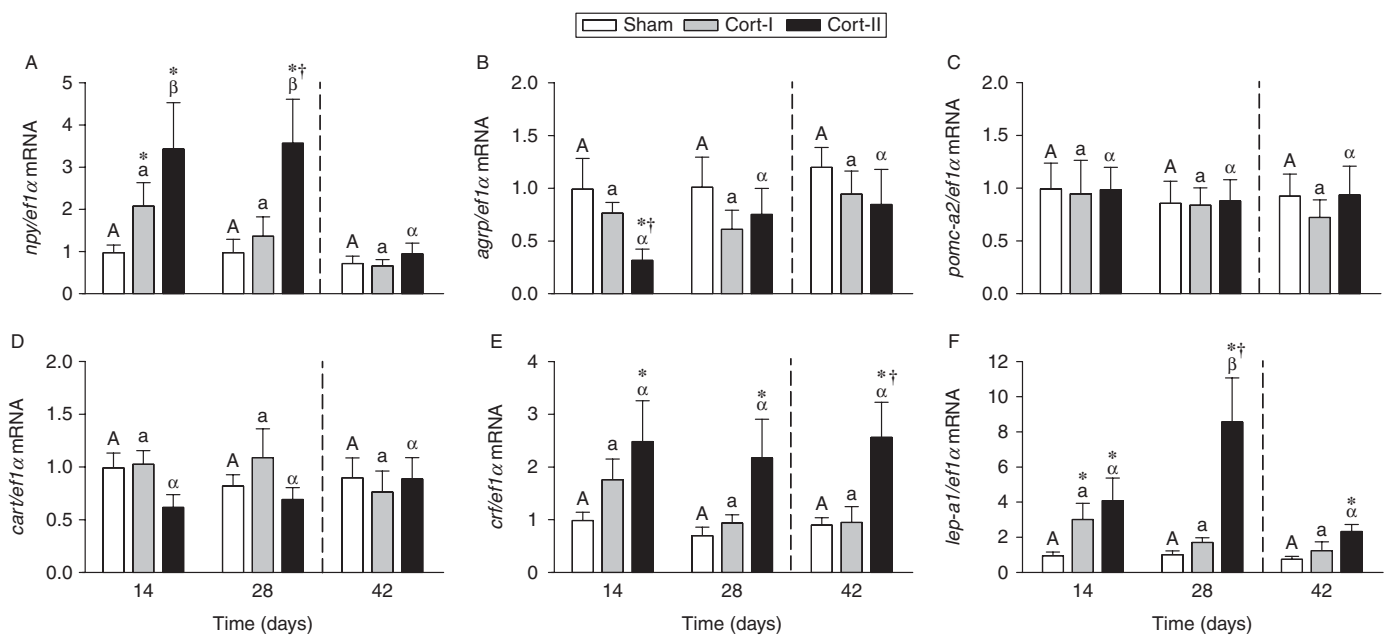

\section{Figure 3}

Brain hypothalamic area (A) neuropeptide $Y(n p y),(B)$ agouti-related protein (agrp), (C) pro-opiomelanocortin A2 (pomc-a2), (D) cocaine- and amphetamine-regulated transcript (cart), and (E) preoptic area corticotropin-releasing factor (crf), and (F) liver leptin-A1 (lep-a1) mRNA expression in rainbow trout implanted intraperitoneally with a microosmotic pump containing either vehicle (Sham), $20 \mu \mathrm{g}$ (Cort-l) or $40 \mu \mathrm{g}$ cortisol/g BW (Cort-II). Cortisol treatments terminated at 34 day as indicated by the dashed line. The mRNA expression values are normalized with elongation factor $1 \alpha(e f 1 \alpha)$ and the expression ratios are presented relative to the Sham 14-day treatment. Statistical differences between values were determined by a two factor ANOVA and Holm-Sidak post-hoc
(C) 2015 Society for Endocrinology Printed in Great Britain test: $n p y$ (treatment: $P<0.001$, time: $P<0.001$, treatment $\times$ time: $P=0.253$ ), agrp (treatment: $P=0.004$, time: $P=0.115$, treatment $\times$ time: $P=0.418$ ), pomc-a2 (treatment: $P=0.826$, time: $P=0.943$, treatment $\times$ time: $P=0.994$ ), cart (treatment: $P=0.319$, time: $P=0.875$, treatment $\times$ time: $P=0.441$ ), crf (treatment: $P<0.001$, time: $P=0.107$, treatment $\times$ time: $P=0.485$ ) and lep-a1 (treatment: $P<0.001$, time: $P=0.012$, treatment $\times$ time: $P=0.102$ ) mRNA expression. Bars for a given parameter and treatment that do not share a common letter are different from one another. At a given time, a difference from the Sham treatment is indicated by * and a difference between the cortisol treatments is indicated by $+(P<0.05)$. Values are means+S.E.M. $(n=8)$.

Published by Bioscientifica Ltd 


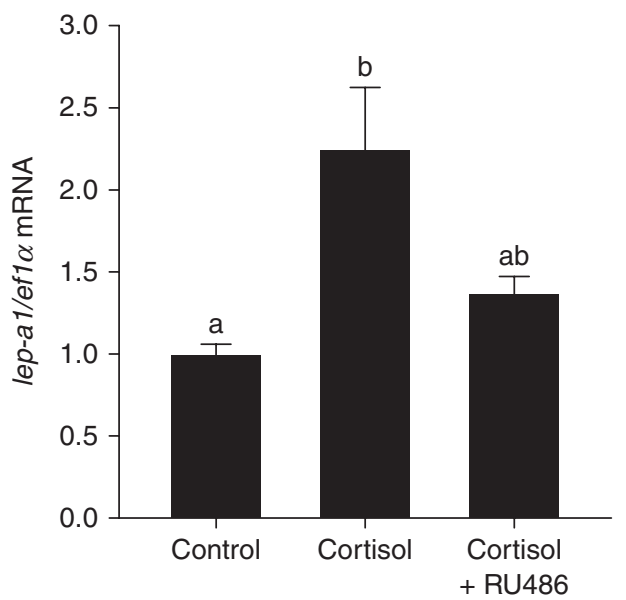

Figure 4

Effects of cortisol on leptin-A1 (lep-a1) mRNA expression in primary culture of rainbow trout hepatocytes. Hepatocytes were exposed to either control (containing $0.01 \%$ ethanol as vehicle), cortisol $(100 \mathrm{ng} / \mathrm{ml})$, or a combination of cortisol $(100 \mathrm{ng} / \mathrm{ml})$ and RU486 $(1,000 \mathrm{ng} / \mathrm{ml})$ and sampled $24 \mathrm{~h}$ after treatment. Statistical differences between values were determined by a one way ANOVA and Holm-Sidak post-hoc test. Bars that do not share a common letter are different from one another. Values are means + S.E.M. ( $n=6$ independent fish).

in Sham at 42 days (Fig. 6B). Relative to the Sham treatment, the cortisol treatments were associated with 1.4- to 2.0-fold increases in liver igfbp1 and igfbp 2 mRNA levels at 14 days, 1.4- to 2.4-fold increases in igfbp1 gene expression at 28 days and a 1.9 -fold increase in igfbp1 gene expression in the Cort-II treatment at 42 days (Fig. 6C and D).

Overall, throughout the 42-day experiment, we observed a relatively weak positive correlation between the circulating levels of IGF1 and SGR in the sham treatment $(R=0.541, P=0.01$, data not shown). During the cortisol dosing period, a similar correlation was observed between plasma IGF1 and SGR in the Cort-I treatment $(R=0.552, P=0.06)$, but there was no relationship between these two parameters in the Cort-II treatment $(R=-0.008, P=0.98)$. In contrast, the recovery phase at 42 days was characterized by stronger positive correlations between SGR and plasma IGF1 levels in the Cort-I $(R=0.849, P=0.03)$ and Cort-II $(R=0.856, P=0.03)$ treatments.

\section{Plasma and tissue metabolite levels}

Plasma glucose levels in the sham treatment remained unchanged throughout the experiment (Fig. 7A). In the Cort-I treatment, plasma glucose concentrations did not differ from those in the Sham. In contrast, glucose levels in
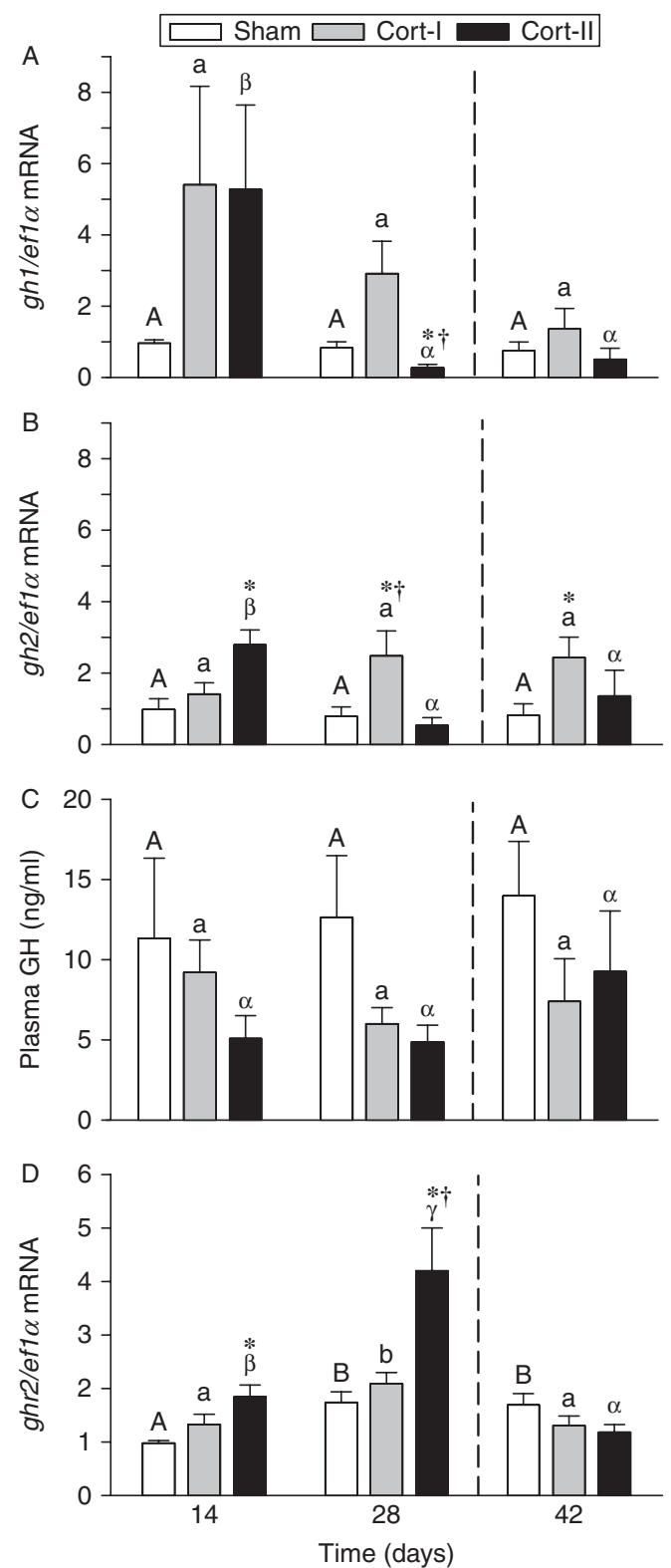

Figure 5

(A) Pituitary growth hormone 1 (gh1) and (B) gh2 mRNA expression, (C) plasma $\mathrm{GH}$, and (D) liver $\mathrm{GH}$ receptor type 2 ( $g h r 2)$ mRNA expression in rainbow trout implanted intraperitoneally with a micro-osmotic pump containing either vehicle (Sham), $20 \mu \mathrm{g}$ (Cort-I) or $40 \mu \mathrm{g}$ cortisol/g BW (CortII). Cortisol treatments terminated at 34 days as indicated by the dashed line. The mRNA expression values are normalized with elongation factor $1 \alpha$ (ef1 $\alpha$ ) and the expression ratios are presented relative to the Sham 14-day treatment. Statistical differences between values were determined by a two factor ANOVA and Holm-Sidak post-hoc test: gh1 (treatment: $P=0.002$, time: $P<0.001$, treatment $\times$ time: $P<0.001$ ), gh2 (treatment: $P<0.001$, time: $P=0.055$, treatment $\times$ time: $P<0.001$ ), plasma GH (treatment: $P=0.007$, time: $P=0.986$, treatment $\times$ time: $P=0.582$ ) and $g h r$ (treatment: $P=0.003$, time: $P<0.001$, treatment $\times$ time: $P<0.001$ ). Bars for a given parameter and treatment that do not share a common letter are different from one another. At a given time, a difference from the Sham treatment is indicated by * and a difference between the cortisol treatments is indicated by $+(P<0.05)$. Values are means + S.E.M. $(n=8)$.

Published by Bioscientifica Ltd 

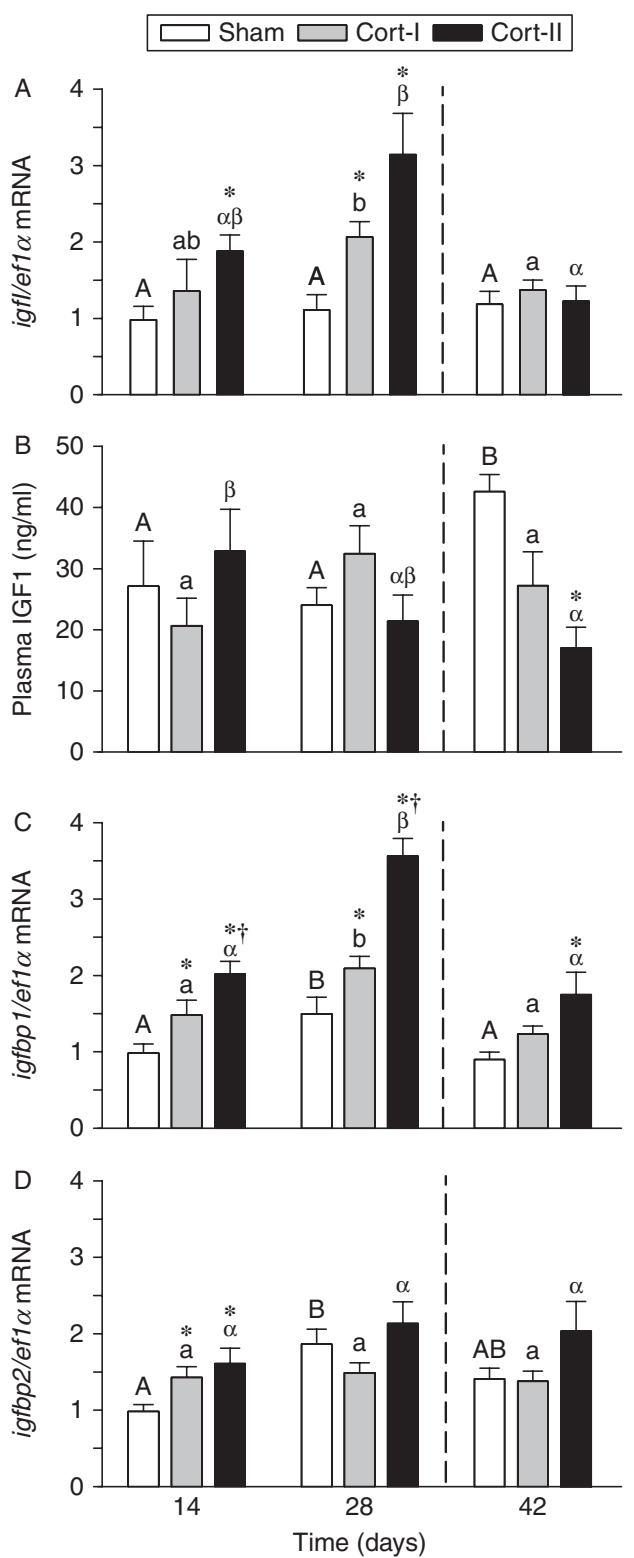

\section{Figure 6}

(A) Liver insulin-like growth factor I (igf1) mRNA expression, (B) plasma IGF1, (C) IGF binding protein 1 (igfbp1) mRNA expression and (D) igfbp2 mRNA expression in rainbow trout implanted intraperitoneally with a microosmotic pump containing either vehicle (Sham), $20 \mu \mathrm{g}$ (Cort-I) or $40 \mu \mathrm{g}$ cortisol/g BW (Cort-II). Cortisol treatments terminated at 34 days as indicated by the dashed line. The mRNA expression values are normalized with elongation factor $1 \alpha(e f 1 \alpha)$ and the expression ratios are presented relative to the Sham 14-day treatment. Statistical differences between values were determined by a two factor ANOVA and Holm-Sidak post-hoc test: igf1 (treatment: $P<0.001$, time: $P=0.006$, treatment $\times$ time: $P=0.048$ ), plasma IGF1 (treatment: $P=0.148$, time: $P=0.719$, treatment $\times$ time: $P=0.003$ ), igfbp 1 (treatment: $P<0.001$, time: $P=0.055$, treatment $\times$ time: $P=0.692$ ) and igfbp2 (treatment: $P=0.002$, time: $P=0.002$, treatment $\times$ time: $P=0.12$ ). Bars for a given parameter and treatment that do not share a common letter are different from one another. At a given time, a difference from the Sham treatment is indicated by * and a difference between the cortisol treatments is indicated by $+(P<0.05)$. Values are means + S.E.M. $(n=8)$. the Cort-II treatment were 50 and $46 \%$ higher than in the Sham at 14 and 28 days respectively. At 42 days, the cortisol-treated fish had plasma glucose levels that did not differ from those in the sham-treated fish. At the tissue level, liver (Fig, 7B) and muscle (Fig. 7C) glycogen content remained unchanged in the Sham fish over the course of the experiment. In general, the cortisol treatments elicited dose-dependent decreases in liver glycogen at 14 and 28 days, but only the $80 \%$ reduction in the Cort-II treatment at 28 days reached statistical significance. At 42 days, liver glycogen content in the Cort-I and -II treatments were still $57 \%$ lower than in the Sham treatment. In contrast, the cortisol treatments did not affect white muscle glycogen content. In the liver, both cortisol treatments reduced lipid content by $72 \%$ at 14 days (Fig. 7D). Although liver lipid content remained low in the cortisol-treated fish throughout the experiment, the concentration of this metabolite decreased over time in the Sham treatment such that the cortisol treatments no longer differed from the Sham at 28 and 42 days. In white muscle, while lipid content in the sham treatment remained unchanged over 42 days and the Cort-I treatment had no effect, the Cort-II treatment reduced lipid stores by $50 \%$ relative to Sham at 28 and 42 days but the difference only reached statistical significance at 28 days (Fig. 7E).

\section{Discussion}

It is generally accepted that chronic stress reduces growth in fish primarily through the actions of cortisol but the specific mechanisms by which chronic cortisol exposure inhibits growth remain poorly understood. In this study, we show that chronic exposure to moderate cortisol levels suppress food intake and provide original evidence implicating liver leptin, POA CRF and hypothalamic AgRP as potential mediators of the appetite-suppressing effects of cortisol in rainbow trout. Moreover, we demonstrate that the growth-inhibiting effects of chronic cortisol exposure are associated with complex adjustments within the GH/IGF axis and a mobilization of fuel reserves. Specifically, our findings indicate that hepatic IGFBP1 plays an important role in reducing the growth-promoting effects of IGF1 during both cortisol exposure and recovery.

Rainbow trout in this study were exposed to physiological cortisol levels averaging $\sim 70$ and $\sim 116 \mathrm{ng} / \mathrm{ml}$ for a 34-day period. While fish can habituate to some chronic stressors, sustained plasma cortisol levels similar to those used in this study have been observed in response to diverse stressors of anthropogenic and natural origins. For example, chronic exposure to aluminum, copper,

Published by Bioscientifica Ltd. 


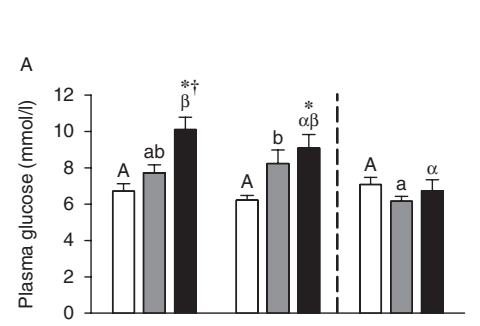

D

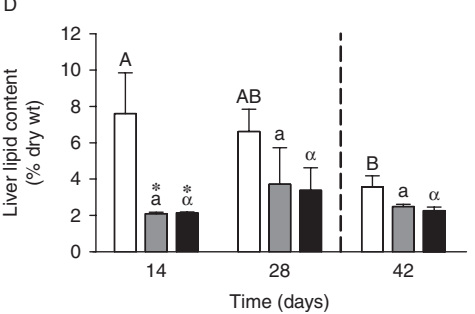

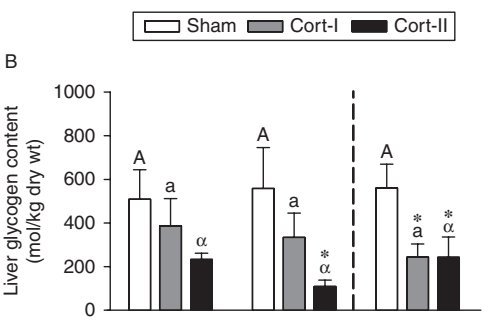

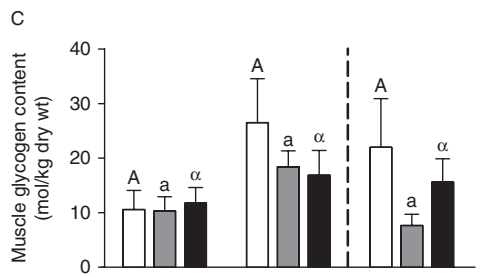

E

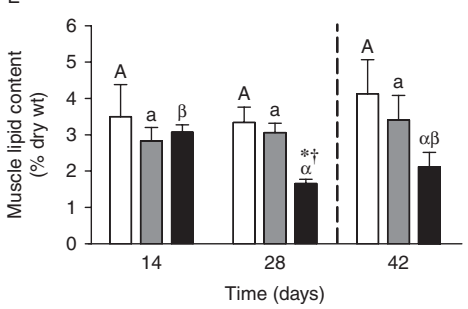

\section{Figure 7}

(A) Plasma glucose, liver (B) glycogen and (D) lipid content, and white muscle $(C)$ glycogen and $(E)$ lipid content in rainbow trout implanted intraperitoneally with a micro-osmotic pump containing either vehicle (Sham), $20 \mathrm{~g}$ (Cort-I) or $40 \mu \mathrm{g}$ cortisol/g BW (Cort-II). Cortisol treatments terminated at 34 days as indicated by the dashed line. Statistical differences between values were determined by a two factor ANOVA and Holm-Sidak post-hoc test: plasma glucose (treatment: $P<0.001$, time: $P=0.007$, treatment $\times$ time: $P=0.014$ ), liver glycogen (treatment: $P<0.001$, time:

selenium or low environmental $\mathrm{pH}$ can result in prolonged elevations in plasma cortisol levels (Craig et al. 2009, Wiseman et al. 2011, Kennedy \& Picard 2012, Grassie et al. 2013). In salmonids, sustained increases in cortisol levels are also associated with social subordination (Gilmour et al. 2005) and with specific phases of the life cycle such as smolting (Nilsen et al. 2008) and sexual maturation (Fuzzen et al. 2011). In fact, plasma cortisol levels can reach several hundred $\mathrm{ng} / \mathrm{ml}$ and remain elevated for weeks to months in sexually mature and migrating Pacific salmon (Carruth et al. 2000, Hinch et al. 2006, Westring et al. 2008). As such, our findings contribute to our understanding of the mechanisms underlying the dynamic changes in food intake, growth and energy mobilization that characterize various chronic stressors and life history transitions.

Consistent with the negative feedback effects of glucocorticoids on pituitary pomc expression and plasma ACTH levels in other fish species (Pickering et al. 1987, Rotllant et al. 2001, Karsi et al. 2005), we show that moderate sustained increases in cortisol levels can chronically decrease pituitary pomc-a2 expression and plasma ACTH levels in rainbow trout. Moreover, we provide novel evidence that the negative feedback effects of cortisol on plasma ACTH can persist for at least 8 days
$P=0.358$, treatment $\times$ time: $P=0.733$ ), muscle glycogen (treatment: $P=0.664$, time: $P=0.123$, treatment $\times$ time: $P=0.696$ ), liver lipid (treatment: $P<0.001$, time: $P=0.167$, treatment $\times$ time: $P=0.237$ ) and muscle lipid (treatment: $P=0.010$, time: $P=0.572$, treatment $\times$ time: $P=0.199$ ). Bars for a given parameter and treatment that do not share a common letter are different from one another. At a given time, a difference from the Sham treatment is indicated by * and a difference between the cortisol treatments is indicated by $+(P<0.05)$. Values are means + S.E.M. $(n=8)$.

beyond the return of cortisol to baseline levels. In contrast, although cortisol has been shown to decrease POA crf gene expression in a few fish species (reviewed by Bernier et al. 2009), and NPO CRF immunoreactive neurons co-express GRs in rainbow trout (Teitsma et al. 1998), chronically elevated cortisol levels in this study were associated with a sustained increase in POA crf mRNA levels. Similarly, suppression of GR signaling in rainbow trout using the GR antagonist RU486 reduces POA crf mRNA levels (Doyon et al. 2006, Alderman et al. 2012). Together, these results suggest that cortisol has a positive feedback effects on POA crf gene expression in rainbow trout.

The marked reductions in food intake elicited by both cortisol treatments throughout the dosage period show that cortisol is a potent anorexigenic factor in rainbow trout. Similarly, chronic plasma cortisol elevations have previously been shown to suppress feeding in rainbow trout (Gregory \& Wood 1999), channel catfish (Peterson \& Small 2005) and sea bass (Dicentrarchus labrax; Leal et al. 2011), although the cortisol dosages used in these studies resulted in plasma cortisol levels that were at least two-times higher than those of the Cort-II treatment. In goldfish, chronic treatment with high plasma cortisol levels $(\sim 270 \mathrm{ng} / \mathrm{ml})$ also inhibited food intake, but lower levels $(\sim 50 \mathrm{ng} / \mathrm{ml})$ had a stimulatory effect

Published by Bioscientifica Ltd. 
(Bernier et al. 2004). Comparison of our previous results in goldfish to those obtained in this study where plasma levels of $\sim 70 \mathrm{ng} / \mathrm{ml}$ effectively halved food intake suggest marked species differences in the actions of cortisol on the regulation of food intake in fish. The sustained inhibitory effects of both cortisol treatments on food intake during recovery also provide novel evidence that cortisol can have a lasting inhibitory effect on appetite in rainbow trout.

The cortisol-induced changes in gene expression of appetite-regulating signals observed in this study suggest that several factors mediate the appetite-suppressing effects associated with chronic plasma cortisol elevations in rainbow trout. Consistent with the stimulatory effects of glucocorticoids on the expression and secretion of leptin from adipocytes in mammals (Lee \& Fried 2009), our in vitro results demonstrate that physiological concentrations of cortisol directly stimulate lep-a1 mRNA levels through GRs in rainbow trout hepatocytes. Given the anorexigenic effects of leptin (Murashita et al. 2008, Aguilar et al. 2010, MacDonald et al. 2014) and CRF (Bernier 2006, Ortega et al. 2013) in rainbow trout, the inverse relationship between the expression of these genes and food intake during the dosage and recovery periods suggest that liver leptin and POA CRF mediate at least a portion of the appetite-suppressing effects of cortisol in this species. Whether the cortisol-mediated increase in hepatic lep-a1 gene expression translates into an increase in circulating leptin levels, and whether leptin stimulates CRF release in fish as it does in mammals (Roubos et al. 2012) remain to be determined. The cortisol-induced reduction in the expression of the orexigenic signal AgRP (Cerdá-Reverter et al. 2011) suggest that this hypothalamic factor may also contribute to the anorexic effects of cortisol. In contrast, we found no evidence that the anorexigenic POMC and CART neurons of the hypothalamus contribute to the cortisol feeding response. Although the cortisol treatments in this study stimulated the hypothalamic gene expression of the orexigenic factor NPY as in goldfish (Bernier et al. 2004), clearly the current experimental conditions favored an anorectic response over an orexigenic one. Finally, since high plasma glucose and fatty acid levels inhibit food intake in rainbow trout and there is evidence that hypothalamic glucosensing and fatty acid-sensing systems are involved in regulating the expression of appetite-regulating genes in this species (Polakof et al. 2011, Librán-Pérez et al. 2012), we suggest that cortisol may inhibit food intake indirectly via its hyperglycemic and lipolytic effects. In fact, as observed in this study, rainbow trout reared under stressful conditions induced by high stocking density and made hyperglycemic are characterized by elevated hypothalamic CRF and NPY mRNA levels (Conde-Sieira et al. 2010).

Our results concur with previous studies in rainbow trout (Barton et al. 1987, Gregory \& Wood 1998, De Boeck et al. 2001) and other fish species (e.g. Bernier et al. 2004, Peterson \& Small 2005, Leal et al. 2011) showing that chronically elevated cortisol levels inhibit growth. In addition, our results demonstrate that the factors contributing to the growth-suppressing effects of cortisol are differentially recruited according to plasma cortisol levels. The fact that Cort-II inhibited mass gained, fork length and CF to a greater extent than Cort-I despite having similar effects on food intake suggests that the relative contribution of reduced food intake to the growthsuppressing effects of cortisol is superseded by factors that reduce feed conversion efficiency when plasma cortisol levels increase above $\sim 70 \mathrm{ng} / \mathrm{ml}$ in rainbow trout. In fish chronically treated with cortisol, lower feed conversion efficiencies may result from a reduction in nutrient absorption in the gut, an increase in metabolic rate, a mobilization of fuel reserves and an inhibition of the growth-promoting effects of the GH/IGF axis (Davis et al. 1985, Barton et al. 1987, Gregory \& Wood 1999, Mommsen et al. 1999, De Boeck et al. 2001, Small et al. 2006).

In this study, chronic cortisol had opposite effects on $\mathrm{GH}$ production and circulating levels. Consistent with the presence of glucocorticoid response elements in the rainbow trout gh1 and gh2 promotor (Yang et al. 1997), we show that chronic cortisol can stimulate pituitary $g h 1$ and $g h 2$ transcription but the effects are complex, dependent on both exposure duration and dosage, and unexpectedly associated with a reduction in plasma GH levels. In general, cortisol and stressors have equivocal effects on plasma GH levels in teleosts. In salmonids, whereas acute stressors either have no effect or decrease plasma GH levels, chronic stressors can increase circulating GH levels (Pickering et al. 1991, McCormick et al. 1998, Wilkinson et al. 2006, Shepherd et al. 2011, Nakano et al. 2013). Given the complexity of the neuroendocrine control of GH secretion (Canosa et al. 2007), the inhibitory effects of cortisol on the plasma levels of the GH secretagogue ghrelin (Pankhurst et al. 2008, Janzen et al. 2012) and the presence of GH binding proteins in fish (Sohm et al. 1998), we suggest that the discrepancy between pituitary GH gene transcription and plasma GH levels in this study may result from changes in the multifactorial regulation of pituitary GH secretion and from an increase in the circulating levels of GH binding

Published by Bioscientifica Ltd. 
proteins. Overall, even though IGFs are recognized as the primary mediators of the growth-promoting effects of the GH/IGF system, since GH can directly stimulate muscle growth in fish (reviewed by Fuentes et al. (2013)) our results indicate that a reduction in plasma GH levels may contribute to the growth-suppressing effects of chronic cortisol in rainbow trout.

In the liver, chronic cortisol exposure resulted in an increase in the expression of several key effectors of the GH/IGF system which together enhanced GH signaling while simultaneously reducing the role of IGF1 as a growth-promoting agent. Consistent with previous observations in salmonids (Pierce et al. 2005, Reindl \& Sheridan 2012) and tilapia (Oreochromis mossambicus; Pierce et al. 2012) cortisol upregulated the expression of hepatic $g h r 2$ in this study. Chronic cortisol exposure also elicited dosedependent increases in hepatic igf 1 expression that closely matched the increase in $g h r 2$ mRNA levels, results which suggest an increase in hepatic GH sensitivity. However, despite eliciting a two- to threefold increase in hepatic igf1 expression, the cortisol treatments did not affect plasma IGF1 levels. Instead, the cortisol-induced increases in hepatic igf1 gene expression were paralleled by changes in liver igfbp1and igfbp 2 mRNA levels after 14 days and by an up-regulation of $i g f b p 1$ expression after 28 days. Since over-expression of low molecular weight IGFBPs can inhibit growth in mammals and fish (reviewed by Duan et al. 2010), we suggest that the cortisol-induced increases in hepatic igfbp 1 and igfbp 2 expression reduced the role of IGF1 as a growth-promoting agent and contributed to the discordant relationship between plasma IGF1 levels and SGR in the Cort-II treatment. In contrast, channel catfish fed cortisol diets that raised plasma cortisol levels to $\sim 180 \mathrm{ng} / \mathrm{ml}$ daily for 4 weeks were characterized by reduced hepatic ghr expression, no change in liver igf mRNA levels, a marked increase in the circulating levels of a low molecular weight IGFBP and depressed plasma IGF1 levels (Peterson \& Small 2005, Small et al. 2006). While differences in dosage, modes of application, and speciesspecific transcriptional regulation of the GH/IGF system may explain the variable effects of chronic cortisol on liver $g h r$ and igf 1 gene expression between studies, our results suggest that an increase in the circulating levels of low molecular weight IGFBPs is a conserved mechanism by which chronic stress inhibits growth in fish.

Eight days post cortisol delivery, the transcriptional activity of the GH/IGF system and the plasma levels of GH and IGF1 indicate that while pituitary GH production and hepatic GH signaling are largely recovered, the growthpromoting actions of IGF1 are still blunted. As observed during the cortisol dosing period, the parallel changes in hepatic ghr2 and igf1 mRNA levels during recovery suggests a cause-and-effect relationship between these elements of the GH/IGF axis. In the Cort-II treatment, the reduced plasma IGF1 concentration and increased hepatic igfbp1 gene expression likely contributed to the sustained growth inhibition. Fasting also increases the circulating levels of low molecular weight IGFBPs in fish (Kelley et al. 2001, Peterson \& Small 2004) and in fasted channel catfish the expression of hepatic igfbp1 can remain elevated even after 15 days of refeeding (Peterson \& Waldbieser 2009). Therefore, beyond the direct actions of cortisol on the transcriptional regulation of igfbp 1 , it is possible that the nutritional status of the cortisol-treated fish contributed to the sustained elevation in liver igfbp1 expression observed during recovery.

Consistent with its key role in regulating energy mobilization during stress, our results implicate cortisol in the catabolism of carbohydrates and lipids. The cortisolmediated changes in HSI, CF, as well as in liver and muscle glycogen and lipid content, also demonstrate that the catabolic effects of cortisol in this study had a much larger impact on the energy reserves of the liver than on those of white muscle. In the liver, numerous fish studies have shown that cortisol increases gluconeogenic capacity (Mommsen et al. 1999, Aluru \& Vijayan 2007, Momoda et al. 2007) and the increases in plasma glucose levels associated with the Cort-II treatment during the dosing period support these findings. The marked reductions in liver glycogen content also suggest that glycogenolysis may have contributed to the cortisol-induced increase in plasma glucose levels. However, whether cortisol has a direct glycolytic effect on the liver is equivocal. Previous studies in fish have shown that cortisol exposure can increase, decrease, or have no effect on liver glycogen content and there is generally no consensus as to the role of cortisol in liver glycogen metabolism (Mommsen et al. 1999, De Boeck et al. 2001, Laiz-Carrión et al. 2003). In tilapia (O. mossambicus), while injections of both cortisol and leptin increase plasma glucose levels, only leptin decreases liver glycogen content (Baltzegar et al. 2014). Given our observation that cortisol stimulates leptin gene expression, an interesting avenue for future research will be to determine whether the glycolytic effects of cortisol in rainbow trout are indirect and mediated by leptin. The reduction in liver and muscle lipid content in the cortisol-treated fish is consistent with the increased lypolytic capacity of chronically stressed fish (Mommsen et al. 1999). Cortisol may deplete lipid reverses in fish by increasing the activity of various lipases

Published by Bioscientifica Ltd 
(Sheridan 1986, Baltzegar et al. 2014) and glycerol utilization (Vijayan et al. 1991), and by reducing the lipogenic potential of the liver (Vijayan et al. 1990, Laiz-Carrión et al. 2003, López-Patino et al. 2014). Moreover, given the known lipolytic properties of $\mathrm{GH}$ in the liver (Björnsson et al. 2002), our results suggest that cortisol may also promote lipolysis via its stimulatory effects on liver $g h r 2$ expression.

Results from this study provide a novel perspective on the multiple interacting pathways by which cortisol contributes to the coordination of energy mobilization and expenditure during chronic stress in fish. Together our findings show that the growth-suppressing effects of chronic cortisol in rainbow trout result from a sustained reduction in food intake, complex transcriptional changes in the GH/IGF1 axis that reduce the growth-promoting actions of GH and IGF1 while enhancing the effects of $\mathrm{GH}$ on the liver, and from a mobilization of carbohydrate and lipid reserves. Specifically, our results suggest that liver leptin and POA CRF are mediators of the anorixegenic effect of chronic cortisol, and that hepatic IGFBP1 likely plays a key role in suppressing the growth-promoting action of IGF1. Finally, our results highlight the need to further define the individual and synergistic actions of cortisol, GH and leptin in the mobilization of energy during chronic stress, as well as the possible indirect actions of cortisol on the regulation of food intake and the GH/IGF1 axis mediated through changes in the levels of circulating metabolites.

\section{Declaration of interest}

The authors declare that there is no conflict of interest that could be perceived as prejudicing the impartiality of the research reported.

\section{Funding}

This research was supported by an Ontario Graduate Scholarship to B N M and by a Natural Sciences and Engineering Research Council of Canada (NSERC) Discovery grant to $\mathrm{N} J \mathrm{~B}$.

\section{Acknowledgements}

We would like to acknowledge the laboratory of Dr Mathilakath M Vijayan for assistance with the primary culture of trout hepatocytes.

\section{References}

Aguilar AJ, Conde-Sieira M, Polakof S, Míguez JM \& Soengas JL 2010 Central leptin treatment modulates brain glucosensing function and peripheral energy metabolism of rainbow trout. Peptides 31 1044-1054. (doi:10. 1016/j.peptides.2010.02.026)
Alderman SL, McGuire A, Bernier NJ \& Vijayan MM 2012 Central and peripheral glucocorticoid receptors are involved in the plasma cortisol response to an acute stressor in rainbow trout. General and Comparative Endocrinology 176 79-85. (doi:10.1016/j.ygcen.2011.12.031)

Aluru N \& Vijayan MM 2007 Hepatic transcriptome response to glucocorticoid receptor activation in rainbow trout. Physiological Genomics 31 483-491. (doi:10.1152/physiolgenomics.00118.2007)

Baltzegar DA, Reading BJ, Douros JD \& Borski RJ 2014 Role for leptin in promoting glucose mobilization during acute hyperosmotic stress in teleost fishes. Journal of Endocrinology 220 61-72. (doi:10.1530/ JOE-13-0292)

Barton BA, Schreck CB \& Barton LD 1987 Effects of chronic cortisol administration and daily acute stress on growth, physiological conditions, and stress responses in juvenile rainbow trout. Diseases of Aquatic Organisms 2 173-185. (doi:10.3354/dao002173)

Bazhan N \& Zelena D 2013 Food-intake regulation during stress by the hypothalamo-pituitary-adrenal axis. Brain research Bulletin 95 46-53. (doi:10.1016/j.brainresbull.2013.04.002)

Bergmeyer HU 1985 Methods of Enzymic Analysis, vol 6. New York, NY: Academic Press.

Bernier NJ 2006 The corticotropin-releasing factor system as a mediator of the appetite-suppressing effects of stress in fish. General and Comparative Endocrinology 146 45-55. (doi:10.1016/j.ygcen.2005.11.016)

Bernier NJ \& Craig PM 2005 CRF-related peptides contribute to stress response and regulation of appetite in hypoxic rainbow trout. American Journal of Physiology. Regulatory, Integrative and Comparative Physiology 289 R982-R990. (doi:10.1152/ajpregu.00668.2004)

Bernier NJ, Berdard N \& Peter RE 2004 Effects of cortisol on food intake, growth, and forebrain neuropeptide $\mathrm{Y}$ and corticotropin-releasing factor gene expression in goldfish. General and Comparative Endocrinology 135 230-240. (doi:10.1016/j.ygcen.2003.09.016)

Bernier NJ, Alderman SL \& Bristow EN 2008 Heads or tails? Stressor-specific expression of corticotropin-releasing factor and urotensin I in the preoptic area and caudal neurosecretory system of rainbow trout Journal of Endocrinology 196 637-648. (doi:10.1677/JOE-07-0568)

Bernier NJ, Flik G \& Klaren PHM 2009 Regulation and contribution of the corticotropic, melanotropic and thyrotropic axes to the stress response in fishes. In Fish Neuroendocrinology, ch 6, pp 235-311. Eds NJ Bernier, G Van Der Kraak, AP Farrell \& CJ Brauner. Burlington, MA, USA: Academic Press. (doi:10.1016/S1546-5098(09)28006-X)

Björnsson BT, Johansson V, Benedet S, Einarsdottir IE, Hildahl J, Augstsson T \& Jönsson E 2002 Growth hormone endocrinology of salmonids: regulatory mechanism and mode of action. Fish Physiology and Biochemistry 27 227-242. (doi:10.1023/B:FISH.0000032728.91152.10)

Breves JP, Hirano T \& Grau EG 2010 Ionoregulatory and endocrine responses to disturbed salt and water balance in Mozambique tilapia exposed to confinement and handling stress. Comparative Biochemistry and Physiology 1554 294-300. (doi:10.1016/j.cbpa.2009.10.033)

Canosa LF, Chang JP \& Peter RE 2007 Neuroendocrine control of growth hormone in fish. General and Comparative Endocrinology 151 1-26. (doi:10.1016/j.ygcen.2006.12.010)

Carruth LL, Dores RM, Maldonado TA, Norris DO, Ruth T \& Jones RE 2000 Elevation of plasma cortisol during the spawning migration of landlocked kokanee salmon (Oncorhynchus nerka kennerlyi). Comparative Biochemistry and Physiology 127 123-131. (doi:10.1016/S03050491(00)00245-5)

Cerdá-Reverter JM, Agulleiro MJ, Guillot R, Sánchez E, Ceinos R \& Rotllant J 2011 Fish melanocortin system. European Journal of Pharmacology 660 53-60. (doi:10.1016/j.ejphar.2010.10.108)

Conde-Sieira M, Agulleiro MJ, Aguilar AJ, Míguez JM, Cerdá-Reverter JM \& Soengas JL 2010 Effect of different glycaemic conditions on gene expression of neuropeptides involved in control of food intake in rainbow trout; interaction with stress. Journal of Experimental Biology 213 3858-3865. (doi:10.1242/jeb.048439)

Craig PM, Al-Timimi H \& Bernier NJ 2005 Differential increase in forebrain and caudal neurosecretory system corticotropin-releasing factor and 
urotensin I gene expression associated with seawater transfer in rainbow trout. Endocrinology 146 3851-3860. (doi:10.1210/en.20050004)

Craig PM, Hogstrand C, Wood CM \& McClelland GB 2009 Gene expression endpoints following chronic waterborne copper exposure in a genomic model organism, the zebrafish, Danio rerio. Physiological Genomics 40 23-33. (doi:10.1152/physiolgenomics.00089.2009)

Crespi EJ, Vaudry H \& Denver RJ 2004 Roles of corticotropin-releasing factor, neuropeptide $\mathrm{Y}$ and corticosterone in the regulation of food intake in Xenopus laevis. Journal of Neuroendocrinology 16 279-288. (doi:10.1111/j.0953-8194.2004.01168.x)

Davis KB, Torrance P, Parker NC \& Suttle MA 1985 Growth, body composition and hepatic tyrosine aminotransferase activity in cortisolfed channel catfish, Ictalurus punctatus Rafinesque. Journal of Fish Biology 27 177-184. (doi:10.1111/j.1095-8649.1985.tb04019.x)

De Boeck G, Alsop D \& Wood C 2001 Cortisol effects on aerobic and anaerobic metabolism, nitrogen excretion, and whole-body composition in juvenile rainbow trout. Physiological and Biochemical Zoology 74 858-868. (doi:10.1086/323796)

DiBattista JD, Levesque HM, Moon TW \& Gilmour KM 2006 Growth depression in socially subordinate rainbow trout Oncorhynchus mykiss: more than a fasting effect. Physiological and Biochemical Zoology 79 675-687. (doi:10.1086/504612)

Doyon C, Leclair J, Trudeau VL \& Moon TW 2006 Corticotropin-releasing factor and neuropeptide Y mRNA levels are modified by glucocorticoids in rainbow trout, Oncorhynchus mykiss. General and Comparative Endocrinology 146 126-135. (doi:10.1016/j.ygcen.2005.10.003)

Duan C, Ren H \& Gao S 2010 Insulin-like growth factors (IGFs), IGF receptors, and IGF-binding proteins: Roles in skeletal muscle growth and differentiation. General and Comparative Endocrinology 167 344-351. (doi:10.1016/j.ygcen.2010.04.009)

Folch J, Lees M \& Stanley GHS 1957 A simple method for the isolation and purification of total lipids from animal tissues. Journal of Biological Chemistry 226 497-509.

Fuentes EN, Valdés JA, Molina A \& Björnsson BT 2013 Regulation of skeletal muscle growth in fish by the growth hormone - insulin-like growth factor system. General and Comparative Endocrinology 192 136-148. (doi:10.1016/j.ygcen.2013.06.009)

Fuzzen M, Bernier NJ \& Van Der Kraak G 2011 Stress and reproduction. In Hormones and Reproduction of Vertebrates, Volume 1: Fishes, pp 103-117. Eds DO Norris \& KH Lopez. San Diego, CA, USA: Elsevier. (doi:10.1016/ B978-0-12-375009-9.10006-2)

Gilmour KM, DiBattista JD \& Thomas JB 2005 Physiological causes and consequences of social status in salmonid fish. Integrative and Comparative Biology 45 263-273. (doi:10.1093/icb/45.2.263)

Grassie C, Braithwaite VA, Nilsson J, Nilsen TO, Teien H-C, Handeland SO, Stefansson SO, Tronci V, Gorissen M, Flik G et al. 2013 Aluminum exposure impacts brain plasticity and behavior in Atlantic salmon (Salmo salar). Journal of Experimental Biology 216 3148-3155. (doi:10.1242/jeb.083550)

Gregory TR \& Wood CM 1999 The effects of chronic plasma cortisol elevation on the feeding behaviour, growth, competitive ability, and swimming performance of juvenile rainbow trout. Physiological and Biochemical Zoology 72 286-295. (doi:10.1086/316673)

Hinch SG, Cooke SJ, Healey MC \& Farrell AP 2006 Behavioural physiology of fish migrations: salmon as a model approach. In Behaviour and Physiology of Fish, pp 239-295. Eds KA Sloman, RW Wilson \& S Balshine. Burlington, MA, USA: Academic Press. (doi:10.1016/S1546-5098(05)24007-4)

Hoskonen P \& Pirhonen J 2006 Effects of repeated handling, with or without anaesthesia, on feed intake and growth in juvenile rainbow trout, Oncorhynchus mykiss (Walbaum). Aquaculture Research $\mathbf{3 7}$ 409-415. (doi:10.1111/j.1365-2109.2005.01448.x)

Janzen WJ, Duncan CA \& Riley LG 2012 Cortisol treatment reduces ghrelin signaling and food intake in tilapia, Oreochromis mossambicus. Domestic Animal Endocrinology 43 251-259. (doi:10.1016/j.domaniend.2012. 04.003)
Kajimura S, Hirano T, Visitacion N, Moriyama S, Aida K \& Grau EG 2003 Dual mode of cortisol action on GH/IGF-I/IGF binding proteins in the tilapia, Oreochromis mossambicus. Journal of Endocrinology 178 91-99. (doi:10.1677/joe.0.1780091)

Karsi A, Waldbieser GC, Small BC \& Wolters WR 2005 Genomic structure of the proopiomelanocortin gene and expression during acute low-water stress in channel catfish. General and Comparative Endocrinology 143 104-112. (doi:10.1016/j.ygcen.2005.03.005)

Kelley KM, Haigwood JT, Perez M \& Galima MM 2001 Serum insulin-like growth factor binding proteins (IGFBPs) as markers for anabolic stress/catabolic conditions in fishes. Comparative Biochemistry and Physiology 129B 229-236. (doi:10.1016/S1096-4959(01)00314-1)

Kennedy CJ \& Picard C 2012 Chronic low pH exposure affects the seawater readiness of juvenile pacific sockeye salmon. Fish Physiology and Biochemistry 38 1131-1143. (doi:10.1007/s10695-011-9599-4)

Laiz-Carrión R, MartínDelRío MP, Miguez JM, Mancera JM \& Soengas JL 2003 Influence of cortisol on osmoregulation and energy metabolism in gilthead seabream Sparus aurata. Journal of Experimental Zoology $\mathbf{9 8 \mathbf { A }}$ 105-118. (doi:10.1002/jez.a.10256)

Leal E, Fernández-Durán B, Guillot R, Ríos D \& Cerdá-Reverter JM 2011 Stressinduced effects on feeding behavior and growth performance of the sea bass (Dicentrarchus labrax): a self-feeding approach. Journal of Comparative Physiology B 181 1035-1044. (doi:10.1007/s00360-011-0585-z)

Leal-Cerro A, Soto A, Martínez MA, Dieguez C \& Casanueva FF 2001 Influence of cortisol status on leptin secretion. Pituitary 4 111-116. (doi:10.1023/A:1012903330944)

Lee M \& Fried SK 2009 Integration of hormonal and nutrient signals that regulate leptin synthesis and secretion. American Journal of Physiology. Endocrinology and Metabolism 296 E1230-E1238. (doi:10.1152/ajpendo. 90927.2008)

Leung LY, Kwong AK, Man AK \& Woo NY 2008 Direct actions of cortisol, thyroxine and growth hormone on IGF-I mRNA expression in sea bream hepatocytes. Comparative Biochemistry and Physiology 151A 705-710. (doi:10.1016/j.cbpa.2008.08.023)

Librán-Pérez M, Polakof S, López-Patiño MA, Míguez JM \& Soengas JL 2012 Evidence of a metabolic fatty acid-sensing system in the hypothalamus and Brockmann bodies of rainbow trout: implications in food intake regulation. American Journal of Physiology. Regulatory, Integrative and Comparative Physiology 302 R1340-R1350. (doi:10.1152/ajpregu.00070.2012)

Londraville RL, Macotela Y, Duff RJ, Easterling MR, Liu Q \& Crespi EJ 2014 Comparative endocrinology of leptin: assessing function in a phylogenetic context. General and Comparative Endocrinology 203 146-157. (doi:10.1016/j.ygcen.2014.02.002)

López-Patiño MA, Hernández-Pérez J, Gesto M, Librán-Pérez M, Míguez JM \& Soengas JL 2014 Short-term time course of liver metabolic response to acute handling stress in rainbow trout, Oncorhynchus mykiss. Comparative Biochemistry and Physiology 168A 40-49. (doi:10.1016/j. cbpa.2013.10.027)

MacDonald LE, Alderman SL, Kramer S, Woo PTK \& Bernier NJ 2014 Hypoxaemia-induced leptin secretion: a mechanism for the control of food intake in diseased fish. Journal of Endocrinology 221 441-455. (doi:10.1530/JOE-13-0615)

McCormick SD, Shrimpton JM, Carey JB, O'Dea MF, Sloan KE, Moriyama S \& Björnsson BT 1998 Repeated acute stress reduces growth rate of Atlantic salmon parr and alters plasma levels of growth hormone, insulin-like growth factor I and cortisol. Aquaculture 168 221-235. (doi:10.1016/S0044-8486(98)00351-2)

Mommsen TP, Vijayan MM \& Moon TW 1999 Cortisol in teleosts: dynamics, mechanisms of action, and metabolic regulation. Reviews in Fish Biology and Fisheries 9 211-268. (doi:10.1023/A:1008924418720)

Momoda TS, Schwindt AR, Feist GW, Gerwick L, Bayne CJ \& Schreck CB 2007 Gene expression in the liver of rainbow trout, Oncorhynchus mykiss, during the stress response. Comparative Biochemistry and Physiology 2D 303-315. (doi:10.1016/j.cbd.2007.06.002)

Murashita K, Uji S, Yamamoto T, Rønnestad I \& Kurokawa T 2008 Production of recombinant leptin and its effects on food intake in

Published by Bioscientifica Ltd. 
rainbow trout (Oncorhynchus mykiss). Comparative Biochemistry and Physiology 150B 377-384. (doi:10.1016/j.cbpb.2008.04.007)

Nakano T, Afonso LOB, Beckman BR, Iwama GK \& Devlin RH 2013 Acute physiological stress down-regulates mRNA expressions of growthrelated genes in coho salmon. PLOS ONE 8 e71421. (doi:10.1371/ journal.pone.0071421)

Nilsen TO, Ebbesson LOE, Kiilerich P, Björnsson BT, Madsen SS, McCormick SD \& Stefansson SO 2008 Endocrine systems in juvenile anadromous and landlocked Atlantic salmon (Salmo salar): seasonal development and seawater acclimation. General and Comparative Endocrinology 155 762-772. (doi:10.1016/j.ygcen.2007.08.006)

Ortega VA, Lovejoy DA \& Bernier NJ 2013 Appetite-suppressing effects and interactions of centrally administered corticotropin-releasing factor, urotensin I and serotonin in rainbow trout (Oncorhynchus mykiss). Frontiers in Neuroscience 7 1-10. (doi:10.3389/fnins.2013.00196)

Pankhurst NW \& Van der Kraak G 1997 Effects of stress on reproduction and growth of fish. In Fish Stress and Health in Aquaculture. Society for Experimental Biology, Seminar Series 62, pp 73-93. Eds GK Iwama, AD Pickering, JP Sumpter \& CB Schreck. Cambridge, UK: Cambridge University Press.

Pankhurst NW, Ludke SL, King HR \& Peter RE 2008 The relationship between acute stress, food intake, endocrine status and life history stage in juvenile farmed Atlantic salmon, Salmo salar. Aquaculture $\mathbf{2 7 5}$ 311-318. (doi:10.1016/j.aquaculture.2008.01.001)

Peterson BC \& Small BC 2004 Effects of fasting on circulating IGF-binding proteins, glucose, and cortisol in channel catfish (Ictalurus punctatus). Domestic Animal Endocrinology 26 231-240. (doi:10.1016/j.domaniend. 2003.10.005)

Peterson BC \& Small BC 2005 Effects of exogenous cortisol on the GH/IGF-I/IGFBP network in channel catfish. Domestic Animal Endocrinology 28 391-404. (doi:10.1016/j.domaniend.2005.01.003)

Peterson BC \& Waldbieser GC 2009 Effects of fasting on IGF-I, IGF-II, and IGF-binding protein mRNA concentrations in channel catfish (Ictalurus punctatus). Domestic Animal Endocrinology 37 74-83. (doi:10.1016/ j.domaniend.2009.03.004)

Picha ME, Turano MJ, Beckman BR \& Borski RJ 2008 Endocrine biomarkers of growth and applications to aquaculture: a minireview of growth hormone, insulin-like growth factor (IGF)-I, and IGF-binding proteins as potential growth indicators in fish. North American Journal of Aquaculture 70 196-211. (doi:10.1577/A07-038.1)

Pickering AD 1992 Rainbow trout husbandry: management of the stress response. Aquaculture 100 125-139. (doi:10.1016/0044-8486(92) 90354-N)

Pickering AD \& Pottinger TG 1989 Stress responses and disease resistance in salmonid fish: effects of chronic elevation of plasma cortisol. Fish Physiology and Biochemistry 7 253-258. (doi:10.1007/BF00004714)

Pickering AD, Pottinger TG \& Sumpter JP 1987 On the use of dexamethasone to block the pituitary-interrenal axis in the brown trout, Salmo trutta L. General and Comparative Endocrinology 65 346-353. (doi:10.1016/0016-6480(87)90119-5)

Pickering AD, Pottinger TG, Sumpter JP, Carragher JF \& Le Bail PY 1991 Effects of acute and chronic stress on the levels of circulating growth hormone in the rainbow trout, Oncorhynchus mykiss. General and Comparative Endocrinology 83 86-93. (doi:10.1016/00166480(91)90108-I)

Pierce AL, Fukada H \& Dickhoff WW 2005 Metabolic hormones modulate the effect of growth hormone $(\mathrm{GH})$ on insulin-like growth factor-I (IGF-I) mRNA level in primary culture of salmon hepatocytes. Journal of Endocrinology 184 341-349. (doi:10.1677/joe.1.05892)

Pierce AL, Breves JP, Moriyama S, Uchida K \& Grau EG 2012 Regulation of growth hormone $(\mathrm{GH})$ receptor (GHR1 and GHR2) mRNA level by GH and metabolic hormones in primary cultured tilapia hepatocytes. General and Comparative Endocrinology 179 22-29. (doi:10.1016/j.ygcen. 2012.07.010)
Polakof S, Mommsen TP \& Soengas JL 2011 Glucosensing and glucose homeostasis: from fish to mammals. Comparative Biochemistry and Physiology 160B 123-149. (doi:10.1016/j.cbpb.2011.07.006)

Reindl KM \& Sheridan MA 2012 Peripheral regulation of the growth hormone-insulin-like growth factor system in fish and other vertebrates. Comparative Biochemistry and Physiology 163A 231-245. (doi:10.1016/j.cbpa.2012.08.003)

Rotllant J, Balm PHM, Pérez-Śnchez J, Wendelaar-Bonga SE \& Tort L 2001 Pituitary and interrenal function in gilthead sea bream (Sparus aurata L., Teleostei) after handling and confinement stress. General and Comparative Endocrinology 121 333-342. (doi:10.1006/gcen.2001.7604)

Roubos EW, Dahmen M, Kozicz T \& Xu L 2012 Leptin and the hypothalamo-pituitary-adrenal stress axis. General and Comparative Endocrinology 177 28-36. (doi:10.1016/j.ygcen.2012.01.009)

Saera-Vila A, Calduch-Giner JA, Prunet P \& Perez-Sanchez J 2009 Dynamics of liver GH/IGF axis and selected stress markers in juvenile gilthead sea bream (Sparus aurata) exposed to acute confinement: differential stress response of growth hormone receptors. Comparative Biochemistry and Physiology 154A 197-203. (doi:10.1016/j.cbpa.2009. 06.004)

Sathiyaa R, Campbell T \& Vijayan MM 2001 Cortisol modulates hsp90 mRNA expression in primary cultures of trout hepatocytes. Comparative Biochemistry and Physiology 129B 679-685. (doi:10.1016/S1096-4959 (01)00373-6)

Schram E, Verdegem MCJ, Widjaja RTOBH, Kloet CJ, Foss A, Schelvis-Smit R, Roth B \& Imsland AK 2009 Impact of increased flow rate on specific growth rate of juvenile turbot (Scophthalmus maximus, Rafinesque 1810). Aquaculture 292 46-52. (doi:10.1016/j.aquaculture. 2009.03.020)

Shepherd BS, Aluru N \& Vijayan MM 2011 Acute handling disturbance modulates plasma insulin-like growth factor binding proteins in rainbow trout (Oncorhynchus mykiss). Domestic Animal Endocrinology 40 129-138. (doi:10.1016/j.domaniend.2010.09.007)

Sheridan MA 1986 Effects of thyroxin, cortisol, growth hormone and prolactin on lipid metabolism of coho salmon, Oncorhynchus kisutch, during smoltification. General and Comparative Endocrinology 64 220-238. (doi:10.1016/0016-6480(86)90007-9)

Shimizu M, Swanson P, Fukada H, Hara A \& Dickhoff WW 2000 Comparison of extraction methods and assay validation for salmon insulin-like growth factor-I using commercially available components. General and Comparative Endocrinology 119 26-36. (doi:10.1006/gcen. 2000.7498)

Small BC, Murdock CA, Waldbieser GC \& Peterson BC 2006 Reduction in channel catfish hepatic growth hormone receptor expression in response to food deprivation and exogenous cortisol. Domestic Animal Endocrinology 31 340-356. (doi:10.1016/j.domaniend.2005.12.003)

Small BC, Davis KB \& Peterson BC 2008 Elucidating the effects of cortisol and stress on economically important traits in channel catfish. North American Journal of Aquaculture 70 223-235. (doi:10.1577/A07-031.1)

Sohm F, Manfroid I, Pezet A, Rentier DF, Rand WM, Kelly PA, Boeuf G, Postel VMC \& De LA 1998 Edery mIdentification and modulation of a growth hormone-binding protein in rainbow trout (Oncorhynchus mykiss) plasma during seawater adaptation. General and Comparative Endocrinology 111 216-224. (doi:10.1006/gcen.1998.7106)

Swanson P 1994 Radioimmunoassays for fish growth hormone, prolactin and somatolactin. In Biochemistry and Molecular Biology of Fishes, Volume 3: Analytical Techniques, pp 545-556. Eds PW Hochachka \& TP Mommsen. New York, NY, USA: Elsevier. (doi:10.1016/B978-0-44482033-4.50052-0)

Teitsma CA, Anglade I, Toutirais G, Muñoz-Cueto J-A, Saligaut D, Ducouret B \& Kah O 1998 Immunohistochemical localization of glucocorticoid receptors in the forebrain of the rainbow trout (Oncorhynchus mykiss). Journal of Comparative Neurology 401 395-410. (doi:10.1002/(SICI)10969861(19981123)401:3\%3C;395::AID-CNE7\%3E;3.0.CO;2-P)

Trenzado CE, Morales AE \& de la Higuera M 2006 Physiological effects of crowding in rainbow trout, Oncorhynchus mykiss, selected for low and

Published by Bioscientifica Ltd 
high stress responsiveness. Aquaculture 258 583-593. (doi:10.1016/ j.aquaculture.2006.03.045)

Vijayan MM, Ballantyne JS \& Leatherland JF 1990 High stocking density alters the energy metabolism of brook charr, Salvelinus fontinalis. Aquaculture 88 371-381. (doi:10.1016/00448486(90)90162-G)

Vijayan MM, Ballantyne JS \& Leatherland JF 1991 Cortisol-induced changes in some aspects of the intermediary metabolism of Salvelinus fontinalis. General and Comparative Endocrinology 82 476-486. (doi:10.1016/0016-6480(91)90323-X)

Wendelaar Bonga SE 1997 The stress response in fish. Physiological Reviews 77 591-625.

Westring CG, Ando H, Kitahashi T, Bhandari RK, Ueda H, Urano A Dores RM, Sher AA \& Danielson PB 2008 Seasonal changes in CRF-I and urotensin I transcript levels in masu salmon: correlation with cortisol secretion during spawning. General and Comparative Endocrinology 155 26-40. (doi:10.1016/j.ygcen.2007.03.013)
Wilkinson RJ, Porter M, Woolcott H, Longland R \& Carragher JF 2006 Effects of aquaculture related stressors and nutritional restriction on circulating growth factors (GH, IGF-I and IGF-II) in Atlantic salmon and rainbow trout. Comparative Biochemistry and Physiology 145A 214-224. (doi:10.1016/j.cbpa.2006.06.010)

Wiseman S, Thomas JK, McPhee L, Hursky O, Raine JC, Pietrock M, Giesya JP, Hecker M \& Janza DM 2011 Attenuation of the cortisol response to stress in female rainbow trout chronically exposed to dietary selenomethionine. Aquatic Toxicology 105 643-651. (doi:10.1016/j.aquatox.2011.09.002)

Wood AW, Duan C \& Bern HA 2005 Insulin-like growth factor signaling in fish. International Review of Cytology 243 215-285. (doi:10.1016/S00747696(05)43004-1)

Yang B-Y, Chan K-M, Lin C-M \& Chen TT 1997 Characterization of rainbow trout (Oncorhynchus mykiss) growth hormone 1 gene and the promoter region of growth hormone 2 gene. Archives of Biochemistry and Biophysics 340 359-368. (doi:10.1006/abbi.1997.9930)

Received in final form 9 June 2015

Accepted 18 June 2015

Accepted Preprint published online 22 June 2015
() 2015 Society for Endocrinology Printed in Great Britain
Published by Bioscientifica Ltd. 